\title{
Effects of stereotactic surgery on the anterior hypothalamus (HA) on the estrous cycle: Role of the dopaminergic system in spontaneous ovulation in the rat
}

\section{Efectos de la cirugía estereotáxica de abordaje al hipotálamo anterior (HA) sobre el ciclo estral: Papel del sistema dopaminérgico en la ovulación espontánea en la rata}

\author{
MORÁN-PERALES, José Luisł**, SÁNCHEZ-GARCÍA, Octavio, GARCÍA-SUÁSTEGUI, Wendy \\ Argelia and HANDAL-SILVA, Anabella
}

\author{
Benemérita Universidad Autónoma de Puebla-Departamento de Biología y Toxicología de la Reproducción, Instituto de \\ Ciencias
}

ID $1^{\text {st }}$ Author: José Luis, Morán-Perales / ORC ID: 0000-0002-2823-2829, Researcher ID Thomson: S-5803-2018, arXiv Author ID: doctor_moran, PubMed Autor ID: moranperales, CVU CONACYT ID: 207096

ID $1^{\text {st }}$ Coauthor: Octavio, Sánchez-García / ORC ID: 0000-0002-2710-8084, Researcher ID Thomson: S-6739-2018, PubMed Autor ID: sanchezgarcia, CVU CONACYT ID: 367319

ID $2^{\text {st }}$ Coauthor: Wendy Argelia, García-Suástegui / ORC ID: 0000-0001-5223-3189, Researcher ID Thomson: S-68312018, PubMed Autor ID: garcia-suastegui, CVU CONACYT ID: 48932

ID $3^{\text {st }}$ Coauthor: Anabella, Handal-Silva / ORC ID: 0000-0002-6915-5655, Researcher ID Thomson: S-6799-2018, PubMed Autor ID: anabellahandal, CVU CONACYT ID: 210819

DOI: $10.35429 / E J R G .2019 .8 .5 .27 .50$

Received March 10, 2019; Accepted June 08, 2019

\section{Abstract}

We evaluated the function of dopaminergic receptors (DAR) of the anterior hypothalamus (AH) on the estral cycle (EC) regulation and spontaneous ovulation by a single microinjection (MI) with the dopaminergic antagonist haloperidol (HLP) in adult rats. One hundred thirty nine rats that exhibit forth-day estral cycles (cyclic animals: $\mathrm{CA}$ ) received a stereotaxic surgery (STXS) on the right, left or both AH sides and were distributed in three different groups with a MI of $1 \mu \mathrm{L}$ of: HLP $(15 \mu \mathrm{g})$ or dimethyl-sulfoxide (vehicle) or other false MI group. All the animals with STXS were sacrificed in next vaginal estrus (VE) exhibited and the ova shed (OS) counted. In sixteen AC, the OS were counted at VE and forming a control group. The STXS affected the animals EC: just 59/139 exhibited a short EC (SEC) with $4.6 \pm 0.1$ days compared with $80 / 139$ that exhibited a long EC (LEC) of $13.6 \pm 0.2$ days. False or HLP MI diminished OS just in animals exhibiting a SEC. STXS affects neuroendocrine processes controlling EC length when cutting dorsal connections to $\mathrm{AH}$. The DAR of the AH participate on ovarian mechanisms of follicular selection.

Anterior hypothalamus, Stereotaxic Surgery, Hypothalamic dopaminergic system

\begin{abstract}
Resumen
Se evaluó el antagonismo de los receptores a dopamina (RDA) en el hipotálamo anterior (HA) en la regulación del ciclo estral (CE) y la ovulación espontánea mediante la microinyección (MI) de haloperidol (HLP) en ratas adultas. Ciento treintainueve ratas con CE regular de cuatro días (animales cíclicos: AC), recibieron cirugía estereotáxica (CETX) en el lado derecho, izquierdo o en ambos lados del HA y se distribuyeron en tres grupos con: $1 \mu \mathrm{L}$ MI de HLP $(15 \mu \mathrm{g})$ o dimetilsulfóxido puro (vehículo) y otro grupo con MI falsa. Todos los animales con CETX se sacrificaron en el siguiente estro vaginal (EV) y se contó el número de ovocitos liberados (NOL). Como grupo control, en 16 AC se les contó el NOL al EV. La CETX afectó el CE de los animales: solo en 59/139 se presentó un CE Corto (CEC) de 4.6 \pm 0.1 días, pero en 80/139 la duración del CE Largo (CEL) fue de 13.6 \pm 0.2 días. Las MI falsas y con HLP disminuyeron el NOL únicamente en los animales que presentaron CEC. La CETX afecta procesos neuroendocrinos que controlan la duración del CE cuando se seccionan vías de conexión dorsales al HA. Los RDA del HA inciden en mecanismos ováricos de selección folicular.
\end{abstract}

Hipotálamo anterior, Cirugía Estereotáxica, Sistema dopaminérgico del hipotálamo

Citation: MORÁN-PERALES, José Luis, SÁNCHEZ-GARCÍA, Octavio, GARCÍA-SUÁSTEGUI, Wendy Argelia and HANDAL-SILVA, Anabella. Effects of stereotactic surgery on the anterior hypothalamus (HA) on the estrous cycle: role of the dopaminergic system in spontaneous ovulation in the rat. ECORFAN Journal-Republic of Guatemala. 2019, 5-8: 27-50

\footnotetext{
* Correspondence to Author (email: moranperales@yahoo.com.mx)

$\dagger$ Researcher contributing first author.
} 


\section{Introduction}

The reproductive functions are the result of the integration of multiple phenomena in which the organs and systems of the body participate, where the nervous system is the main leader of the organism. Its role is essential because the application or suppression of various stimuli: surgical, pharmacological, mechanical, electrical or even biological, in organisms, invariably affect the nervous information and the ability of the organs to respond to them. Thus, it has been widely shown that the nervous system plays a crucial role in the control of reproductive function. In the female, the release of viable gametes is a cyclic event that is subject to nervous control and in turn, immersed in a sequence of immune, neuroendocrine and endocrine phenomena that lead to ovulation (Erickson, 1995).

Gonadotropin secretion is regulated by gonadotropin-releasing hypothalamic hormone: $\mathrm{GnRH}$, whose secretion is controlled by different neurotransmitter systems: amino acids (glutamate, aspartate, glycine, $\square$ aminobutyrate), amines biogenic (adrena-lina, norepinephrine, serotonin, dopamine and histamine), acetylcholine and various neuropeptides (opioids, encephalin, substance $\mathrm{P}$, neuropeptide $\mathrm{Y}$, vasoactive intestinal peptide, angiotensin II, among many others) (Kordon et al, 1994) . It has been widely documented that these neuronal communication systems are modulated by the action of sex steroids produced in the gonads (Fink, 1988).

In rodents, the neurons that secrete GnRH are preferentially located in the septalpreoptic-suprachiasmatic region and in the medial-basal hypothalamus (McCann et al, 1978). According to the information available, the participation of the various neurotransmission systems in the regulation of GnRH secretion varies during the estrous cycle because during this cycle the production of sexual steroids is also variable (Miyake, 1988).

We have shown that dopamine is a key signal for the regulation of the rat estrous cycle, since the antagonism of its receptors, at the systemic level (Domínguez et al, 1987), locally within the anterior hypothalamus (Morán \& Domínguez, 1995) or within the ovary (Venegas et al, 2015), it is able to offset the estrous cycle and induce a delay in the spontaneous ovulation of the rat.

\section{Justification}

Although, our group has worked in recent years analyzing the role of the ovarian dopaminergic signal (Letras et al, 2016; González et al, 2016; Guzmán Herrera, 2018; Venegas Meneses et al, 2017) it remains to be clarified what it is the functional role of dopamine that projects towards the rostral areas of the rat's hypothalamus and that probably participates in the control of gonadotropin secretion and ovarian function at different times of the estrous or ovarian cycle. Therefore, the present work shows the effects of the surgical approach to the anterior hypothalamus in order to analyze the role of dopamine through the pharmacological antagonism of its receptors in this brain region, where the phasic discharge of GnRH is controlled. The works of our group mentioned above, show the important participation of this chemical signal in the control of reproductive function and indicate that attention should be paid to the hormonal status of the female, since it is clear that the function of dopamine is variable throughout the reproductive cycle. Experimental evidence leads us to the reflection of taking into account that when the role of central and peripheral dopaminergic systems in reproductive function is analyzed, attention is required at the moment in which the function of dopamine will be studied. Thus, in the present study we sought to carry out a research work focused on the analysis of dopaminergic antagonism in the anterior hypothalamus on each day of the rat estrous cycle.

\section{Problem}

The surgical technique used in our experimental models to place implants (Morán \& Domínguez, 1995; Morán \& Domínguez, 1997) or to perform micro-injections of dopamine antagonists in the anterior hypothalamus (Méndez \& Morán, $2001 b$ ), poses the methodological difficulty for to ensure that the animals managed to maintain an intracerebral guide cannula that had to remain in the skull throughout the experiment and in addition to taking into account a period of several days for the adaptation of the animals to said cannula, in this work it was decided to reevaluate the Role of dopamine more simply, supported by a high-precision microinjection technique to administer the dopamine antagonist haloperidol on the right and / or left side of the anterior hypothalamus of adult rats that exhibited regular four-day estrous cycles (cyclic animals) .

MORÁN-PERALES, José Luis, SÁNCHEZ-GARCÍA, Octavio, GARCÍASUÁSTEGUI, Wendy Argelia and HANDAL-SILVA, Anabella. Effects of stereotactic surgery on the anterior hypothalamus (HA) on the estrous cycle: role stereotactic surgery on the anterior hypothalamus (HA) on the estrous cycle: role
of the dopaminergic system in spontaneous ovulation in the rat. ECORFAN of the dopaminergic system in spo 
The purpose of the present work was to induce the blocking of dopaminergic receptors one or both sides of the anterior hypothalamus and analyze how spontaneous ovulation is affected and the duration of the estrous cycle, as an indirect indicator of gonadotropin secretion and thus, confirm whether the dopaminergic system of the anterior hypothalamus has a lateralized involvement on the day of estrus.

\section{Objectives}

\section{General objective}

To analyze the effects of local microinjection on the right, left, or both sides of the anterior hypothalamus of the dopamine receptor antagonist haloperidol on gonadotropin secretion, estimated by the duration of the estrous cycle, and spontaneous ovulation of the adult rat.

\section{Specific objectives}

To analyze the effects of local haloperidol microinjection on the right, left or both sides of the anterior hypothalamus at 1:00 p.m. on estrus on the duration of the estrous cycle in adult rats with regular cycles of four days duration.

To analyze the effects of local haloperidol microinjection on the right, left or both sides of the anterior hypothalamus on spontaneous ovulation in the same animals.

\section{Theoretical framework}

In the rat, the hypothalamus occupies the ventral half of the diencephalon; It constitutes about $10 \%$ of the volume of the brain and contains a large number of circuits that contribute to the maintenance of body homeostasis (Kupfermann, 1985). It extends laterally from the walls of the third ventricle to the lateral hypothalamic grooves. It is delimited face-caudally by the optic chiasma (anterior limit) and by the mammillary bodies (posterior limit) (Simerly, 1995).

Taking the third ventricle as a reference, three regions have been described: periventricular, lateral and medial. The periventricular region is that which surrounds the third ventricle.
The lateral one extends from the descending columns of the fornix to the prosencephalic medial fascicle, the medial is located in the middle of the other two regions and contains most of the neuronal clusters called nuclei (Simerly, 1995).

Based on the distribution of its nuclei, the hypothalamus is divided into three areas: anterior, middle and posterior. The anterior hypothalamus contains the preoptic (medial and lateral), suprachiasmatic, supraoptic and anterior nuclei. The middle hypothalamus is formed by the medial, ventromedial, arcuate, tuberal and periventricular nuclei. The posterior hypothalamus contains the mammary nuclei (premamillary, lateral, medial, supramamilar, and intercalated and posterior) (Simerly, 1995).

GnRH is a decapeptide whose primary structure is: PiroGlu-His-Trp-Ser-Tyr-Gly-LeuArg-Pro-Gly-NH2; It is stored in the nerve terminals that converge in the middle eminence. Under the action of certain stimuli, the neurohormone is released into the blood capillaries of the primary plexus of the hypothalamic-pituitary portal system (Barry et al, 1985; Palkovits, 1980). Its release is given in response to action potentials that culminate with the entry of extracellular calcium through voltage-regulated and ligand-regulated $\mathrm{Ca}++$ channels (Fink, 1979 and 1988).

Once GnRH is released into the hypothalamic-pituitary portal system, the decapeptide binds to specific receptors in the gonadotropic membrane (Silverman, 1988). This hormone-receptor complex triggers the synthesis of second messengers that promote the synthesis and secretion of gonadotropins: follicle stimulating hormone (FSH) and luteinizing hormone (LH) (Conn) , 1994; Feder, 1981; Fink et al, 1983).

In the rat and other small mammals, $\mathrm{GnRH}$ is synthesized by specialized hypothalamic neurons (GnRH-ergic neurons) that are predominantly located in the preoptic, anterior hypothalamus and middle hypothalamus regions (McCann et al, 1978). The axons of these GnRH-ergic neurons project towards the middle eminence where the peptide is stored and released under the indirect action of sex steroids that influence different neurotransmitter systems (Kordon et al, 1994). 
The hormone is released into the primary plexus vessels of the hypothalamic-pituitary portal system and transported by blood to the adenohypophysis (Pierce, 1988). In the female rat, the pattern of GnRH secretion varies during the estrous cycle as does the population of its receptors (Miyake, 1988).

The synthesis and release of $\mathrm{GnRH}$ is modulated by the action of steroid hormones (estrogens, progestogens and androgens) and regulated by different neurotransmitters (amino acids, biogenic amines, acetylcholine and neuropeptides) (Fink, 1979; Kordon et al. 1994).

Numerous experimental evidence has shown the importance of the preoptic and hypothalamic anterior areas (generically referred to as the anterior hypothalamus hereafter) in the regulation of mammalian reproductive function (Barraclough \& Wise, 1982; Barraclough, 1983; Clemens et al, 1976; Kalra, 1974; McCann et al, 1978).

In the rat, the electrolytic destruction of the anterior hypothalamus, covering the suprachiasmatic region, results in a lack of ovulation, the development of a polycystic ovary without luteal bodies and persistent vaginal estrus. This allowed us to suggest that the neural centers that regulate follicular development and ovulation are found in the anterior hypothalamus (Everett, 1939; Hillarp, 1949).

In another experiment, rats were used which were induced to block ovulation with an injection of sodium pentobarbital on the day of the proestrus. The electrical stimulation in the anterior hypothalamus of these animals resulted in the pre-ovulation gonadotropin release and induction of ovulation, an effect that was not observed in animals with pre-optic-tube section (Everett \& Radford, 1961; Tajasen \& Everett , 1967). These results suggest that the neural centers that regulate the release of $\mathrm{LH}$, essential for ovulation to occur, are possibly located in the anterior hypothalamus.

In the hemiatrated animal, bilateral lesions of the anterior hypothalamic area or frontal deafferentation between the anterior pituitary and hypothalamic areas blocked compensatory ovarian hypertrophy (D'Angelo \& Kravats, 1960; Hàlasz \& Gorski, 1967).
These evidences suggest that the neural structures related to the increase in the plasma concentration of FSH, which would occur after hemicraction, are located outside the pituitary area and are probably located in the anterior hypothalamic area.

In the castrated female rat, deafferentation between the anterior hypothalamus and the arcuate nucleus results in the decrease in the plasma concentrations of FSH and LH, while in the intact animal said deaferentation does not block ovulation on the morning of estrus. vaginal, even when there are prolonged periods of right-handed. These results were accompanied by the decrease in $\mathrm{GnRH}$ content in the middle eminence (Kalra, 1974). Based on these studies, it has been postulated that the anterior hypothalamus is closely related to the tonic and cyclic release of gonadotropins and that the integrity of the nerve pathways that arrive at the hypothalamus from the anterior part is essential for normal estrales cycle regulation.

These results were corroborated in animals with bilateral lesions of the preoptic area (Clemens et al, 1976). In that study, the ovaries showed fresh luteal bodies as a sign of recent ovulation. When the lesion covered the anterior hypothalamic area, a state of persistent vaginal estrus was observed, with ovulation block and polycystic ovarian formation. Based on these results, it was suggested that nerve connections located in the anterior hypothalamus are necessary for the animal to have normal vaginal cycles and for ovulation to occur.

On the other hand, several studies have shown that the participation of the cholinergic and catecholaminergic systems in the regulation of endocrine and neuroendocrine mechanisms that culminate with ovulation varies during the rat's estrous cycle, which depend on the time and day of the estrous cycle in which these neurotransmission systems are disrupted (Dominguez et al, 1982, 1985 and 1987).

The doses of reserpine (inhibitor of the catecholamine recapture system) necessary to block ovulation are minimal during the days of estrus and right-handed 1; these doses must be doubled to obtain the same effect during the days of right-handed and pro-atrial (Dominguez et al, 1985). 
Likewise, the blockage of cholinergic systems with atropine (Dominguez et al, 1982), of the noradrenergic receptors with propranolol and dopaminergic with haloperidol (Dominguez et al, 1987) also produce differential effects on the processes that culminate with ovulation that depend on the phases of the estrous cycle in which neurotransmission is interrupted; In general, the effect of the drugs was more severe when they were administered during the first half of the estrous cycle.

Dopamine is an endogenous catecholamine whose role as peripheral and central neurotransmitter has been widely described (Tohyama \& Takatsuji, 1998). Dopamine, at the peripheral level has great importance in the carotid body. Small, highly fluorescent cells are found along the paravertebral spine and regulate some of the cardiovascular functions of dopaminergic drugs. For example, the activation of dopamine receptors induces a positive ionotropic effect. Dopaminergic neurons also innervate the renal and gastrointestinal arteries where dopamine induces vasodilation. This action is coupled with the positive ionotropic action in the heart (Carvey, 1998; Litter, 1988).

Dopaminergic neurons that project towards the hypothalamus have their somas concentrated in four regions: A11, A12, A13, A14 (Bjöurklound \& Nobin, 1973):

1) $\mathrm{A}_{11}$ : somas located in the posterior hypothalamus and the ventral thalamus; these somas are the main source of spinal dopaminergic innervation.

2) $\mathrm{A}_{12}$ : somas located in the arcuate nucleus (TIDA) and in the periventricular nucleus (THDA); project their axons to the outer line of the middle eminence and to the intermediate lobe of the pituitary gland.

3) $\mathrm{A}_{13}$ : somas located in the medial uncertain area; project their axons to the anterior hypothalamus, the dorsomedial nucleus of the hypothalamus and the posterior nucleus.

4) $\mathrm{A}_{14}$ : somas located in the rostral portion of the periventricular nucleus; project their axons to the preoptic, periventricular, suprachiasmatic and lateral septal nuclei.
The dopaminergic soma A11, A13 and A14 are generically referred to as incertohyotothalamic system (Bjöurkloud \& Nobin, 1973; Bjöurkloud et al, 1975). Dopaminergic soma A13 and A14 reach areas of the hypothalamus that contain GnRH-ergic somas, so their functions could be involved with the control of the secretion of FSH and LH (Sanhera et al, 1991b).

There is a great diversity of dopamine agonist and antagonist drugs that can act more or less selectively on a type or subtype of receptor. Haloperidol is a drug belonging to the group of butyrophenones widely used as a neuroleptic agent in the treatment of some mental illnesses (Baldessarini, 1989). They are synthetic compounds whose fundamental structure consists of a chain of three carbon atoms attached to a ketone group which in turn is linked to a benzene group; This fundamental structure is called butyrophenone and in this there is a fluorine atom in the para position of the phenylketonic group (Figure 1).

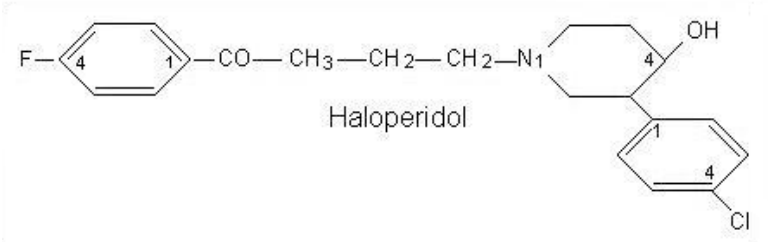

Figure 1. Structure of haloperidol, an antagonist of dopamine receptors. It binds to D1 and D2 receptors, although with greater affinity to the latter.

The action of butyrophenones in experimental animals causes a decrease in motor activity and at high doses produces a state of immobility and catalepsy. In the autonomic nervous system, butyrophenones have an $\alpha$ adrenergic or sympatholytic blocking action and cause the relaxation of the nictitating membranes in the cat, decrease in blood pressure in rats and antagonize the pressor effect of adrenaline and norepinephrine. They also have anticholinergic action (Litter, 1988).

Its main physical characteristics are: white crystalline powder, odorless; slightly bitter; molecular weight of $375.88 \mathrm{~g} / \mathrm{mol}$; practically insoluble in water $(0.02 \mathrm{mg} / \mathrm{ml})$; soluble in acidic solutions (eg $3 \mathrm{mg} / \mathrm{ml}$ in $0.1 \mathrm{~N}$ $\mathrm{HCl}$ ) and in non-polar solvents (chloroform, ketone and benzene); completely soluble in ethanol, methanol and dimethylsulfoxide. 
Given its non-polar characteristics, it easily crosses the biological membrane so it can be easily absorbed through the skin. Haloperidol works by blocking dopamine receptors in the hypothalamus and especially in the pituitary gland at the level of the limbic system and the striatum (Litter, 1988).

Based on different pharmacological studies, haloperidol has been shown to interact antagonistically with both the receptors of the DA1 subtypes (with a relative potency in the order of $\mu \mathrm{M}$ ) and those of the DA2 subtype (with a relative potency in the order of the $n M)$.

Dominguez et al. (1987) evaluated the effects of a dopamine blocker at different stages of the estrous cycle on ovulation and the distribution of the follicular population of the ovaries of the adult rat. In this experiment, rats with regular four-day estrous cycles were used, which were injected with the haloperidol dopamine receptor antagonist $(2.5 \mathrm{mg} / \mathrm{kg}$ weight; i.m.). Groups of animals received a single dose of the drug at 1:00 p.m. of estrus, right-handed, right-handed or proestro and all of them were sacrificed on the morning of the expected estrus.

Haloperidol blocked ovulation significantly when it was administered in estrus and right-handed but was less effective when applied in right-handed and 2-proestro; the follicular population of the ovaries showed a delay in their development and growth that depended on the day of the estrous cycle in which the pharmacological blockade of the dopamine receptors was performed, being more serious these alterations in the animals that received treatment in the first half of the estrous cycle.

These results allowed us to suggest that the dopaminergic information in the first half of the estrous cycle is essential for the sequence of neuroendocrine and endocrine events that culminate in ovulation to be carried out in a normal way. On the other hand, apparently in the second half of the estrous cycle the participation of this system is unclear, since only in half of the animals treated with the drug was ovulation blocked. These results were confirmed in a recent reevaluation, using a novel model of local ovarian antagonism (Venegas et al, 2015).
Morán \& Domínguez (1995) showed that the unilateral blockade of dopaminergic receptors in the anterior hypothalamus on different days of the estrous cycle produces effects that depend on the phase of the cycle in which the pharmacological blockade of dopamine receptors is performed with haloperidol crystals In this experimental model, also the implant with haloperidol on the right or left side of the anterior hypothalamus performed at 1:00 p.m. of the estrus and right-handed was absolutely effective in blocking ovulation; The implant of the drug at 13:00 h of the right-handed 2 produced unclear results, since only $40 \%$ of the animals managed to ovulate, but unlike the study by Dominguez et al. (1987) described in previous lines, the implant Unilateral with haloperidol in the anterior hypothalamus performed at 1:00 p.m. of the proestro was ineffective in preventing ovulation.

These results allowed us to suggest that the dopaminergic information generated in this region of the hypothalamus during the first half of the estrous cycle is necessary for neuroendocrine and endocrine events that culminate with ovulation to be carried out properly and that there is a possibility that different dopaminergic systems are associated in the regulation of the estrous cycle and ovulation, since the effects of the central block in the second half of the rat estrous cycle are different from those of the systemic block.

Based on other experimental evidence, there is controversy about the involvement of the dopaminergic system in the neuronal activity of the hypothalamus nuclei directly related to the regulation of gonadotropin secretion. According to some authors, hypothalamic dopaminergic systems would exert an inhibitory effect on gonadotropic secretion (Choudhury et al, 1974; Ramírez et al, 1984; Tasaka et al, 1985), while for others it would be stimulant (Clemens et al, 1976; MacKenzie et al, 1988 and 1989; Sanhera et al, 1991; Schneider \& McCann, 1970; Vijayan \& McCann, 1978; Weiner \& Ganong, 1978), or who do not participate significantly in this function (Sawyer \& Clifton , 1980). From the results obtained in our laboratory it can be suggested that the differences observed in these studies are based on peculiarities of the experimental models used, since it has been commented that the functions of dopaminergic systems in ovulation control vary during the cycle estral (Domínguez et al, 1987; Morán and Domínguez, 1995).

MORÁN-PERALES, José Luis, SÁNCHEZ-GARCÍA, Octavio, GARCÍASUÁSTEGUI, Wendy Argelia and HANDAL-SILVA, Anabella. Effects of stereofic surgery on the anterior hypothalom (HA) on the estrous cycle: stereotactic surgery on the anterior hypothalamus (HA) on the estrous cycle: role of the dopaminergic system in spontaneous ovulation in the rat. ECORFAN Journal-Republic of Guatemala. 2019 
All these antecedents allow us to suggest that dopamine is a fundamental chemical signal for the control of various brain functions, however there is some controversy about its role in neuroendocrine mechanisms that are coupled to the functioning of the HypothalamusPituitary-Ovary axis, particularly as regards its effect on the control of the secretion of $\mathrm{GnRH}$, gonadotropins: FSH and LH, and ultimately on the ovarian mechanisms that lead to ovulation. We have mentioned in previous lines that much of the dopaminergic information related to the anterior hypothalamus comes from the medial uncertain area of the thalamus. Their somas are located in areas A11, A13 and A14 and express ovarian steroid receptors that regulate the synthesis of dopamine (Sanhera et al, 1991a).

Based on these studies, it is suggested that dopaminergic symptoms of the medial uncertain area could be involved in the mechanisms of retrocontrol of sexual steroids on the central nervous system that participates in the control of gonadotropin release and sexual behavior of the female rat (MacKenzie et al, 1988; MacKenzie et al, 1989; Wilson et al, 1991). The electrolytic destruction of the somas of areas A11, A13 and A14 inhibits the prerelease of LH and prolactin, without affecting the discharge of FSH (Sanhera et al, 1991b).

We have also mentioned that the dopaminergic system participates differentially in the neuroendocrine and endocrine mechanisms that culminate with ovulation, since its variable participation throughout the estrous cycle of the adult rat depends on the time of day when the blockage is performed. Pharmacological of dopamine receptors. Systemic blockade of dopaminergic receptors during estrus and right-handed 1 inhibited ovulation of animals by suppressing the prerelease of LH in $100 \%$ of animals; in righthanded 2, a partial ovulation block was observed, which depended on the time the antagonist was injected; while its administration at 13:00 $\mathrm{h}$ of the proestro reduced the ovulatory response of the animals to $50 \%$ without modifying it when it was administered in the morning or at night (Domínguez et al, 1987). The unilateral implant with haloperidol crystals at the level of the suprachiasmatic region of the anterior hypothalamus produced similar results, with the difference that the implant at 13:00 h on the day of the proestrus did not prevent the ovulation of the animals (Morán \& Domínguez; 1995 ).
These results allow us to suggest that the participation of dopaminergic systems in the control of spontaneous ovulation is different and that the generalized systemic blockade of these systems affects the discharge of gonadotropins by different mechanisms than that regulated by the previous hypothalamus. In another study, it was shown that there is also some degree of lateralization of the dopaminergic system of the anterior hypothalamus on the day of estrus. Implantation of a 1: 1 mixture of haloperidol and cholesterol crystals at 1:00 p.m. from the estrus on the right side of the anterior hypothalamus blocked ovulation on the morning of the expected estrus, but did not do so in animals with implants in the left side (Morán \& Domínguez; 1997). The results of our working group using the experimental model with permanent cannulas inserted in the skull of the animal throughout the experiment, through which implants or micro-injections of the dopamine antagonist were deposited, have opened new paradigms in the study of neuroendocrine regulation of ovulation, since surgical methods and techniques for addressing the anterior hypothalamus invariably lead us to mechanically section the dorsal pathways to this CNS structure.

In these experimental models, the implantation of the cholesterol and haloperidol crystals was performed using an internal cannula of greater length $(7.8 \mathrm{~mm}$ long) than the permanent cannula (4 $\mathrm{mm}$ long) used as a guide for the final implant (Morán \& Domínguez ; 1995 and 1997). Since unilateral implants with pure cholesterol crystals in both studies significantly affected ovulation in the morning of the expected estrus, the possibility was raised that the dorsal thalamic pathways to the anterior hypothalamus that were sectioned by the passage of the internal cannula could be involved in the regulation of the estrous cycle and participate in the mechanisms that control ovulation (Morán \& Domínguez; 1995 and 1997).

In order to analyze the role of the dorsal thalamic pathways to the anterior hypothalamus, we have recently replaced the intracerebral implant technique with crystals with intracerebral microinjection techniques using permanent cannulas of greater length and it was observed that ovulation was blocked in $100 \%$ in animals that received a unilateral microinjection of haloperidol ( $15 \mu \mathrm{g} ; 0.3 \mu \mathrm{g} / \mathrm{min}$; ic) 
On the right or left side of the anterior hypothalamus through a permanent $4 \mathrm{~mm}$ long cannula compared to $60 \%$ ovulation in animals who received said microinjection through a permanent $6 \mathrm{~mm}$ cannula (Méndez Bermúdez \& Morán Perales, 2001; Méndez \& Morán, 2001b; Morán, 2003; Morán et al, 2004). These results allowed us to confirm that the integrity of the dorsal pathways to the anterior hypothalamus is necessary for the proper integration of the neuroendocrine signals that regulate the estrous cycle and ovulation.

In summary and according to our background, we can affirm that at the beginning of the estrous cycle the participation of dopamine systems in the control of gonadotropin secretion and the estrous cycle plays a crucial role and presents a certain degree of laterality.

The purpose of this work was to test whether the pharmacological blockade of dopamine receptors on one or both sides of the anterior hypothalamus on the afternoon of estrus day will cause different effects on the duration of the estrous cycle and on the ovarian function of the adult rat, which will be reflected in differences in the ovulatory capacity of each ovary.

\section{Research Methodology}

\section{Biological Material}

Adult female rats of the CII-ZV strain, with a body weight of 200-250 grams, were maintained under controlled lighting conditions (14 h light / $10 \mathrm{~h}$ dark; lights from 05:00 to 19:00 h) and with free access to water and balanced food. All the animals used in this work, as well as the experimental methodologies in relation to animal welfare, conformed to the Official Mexican Standard NOM-062-ZOO-1999.

\section{General Procedures}

In order to record the estrous cycle in each animal, all of them were taken vaginal smears daily between 09:00 and 10:00 h. Vaginal smears were placed on a glass slide and stained using the hematoxylin-eosin technique to determine the stage of the estrous cycle in each animal and its vaginal cyclic pattern (Luna, 1975) (Figures 2 and 3).
In all experiments, only those animals that had at least three consecutive four-day cycles (cyclic animals) were used: estrus, righthanded, right-handed and proestrous. These animals of regular estrous cycle were assigned to the different experiments.

\section{Stereotactic Surgery}

Between 11:30 and 12:30 $\mathrm{h}$ animals with regular estrous cycles and vaginal estrus were sedated with ketamine ( $25 \mathrm{mg} / \mathrm{kg}$ weight, im; Anesket, Agropecuaria SA de CV) and three minutes later anesthetized with sodium pentobarbital (40 $\mathrm{mg} /$ $\mathrm{kg}$, ip; Anesthesia; Smith Kline Norden of Mexico). Once immobile, the animals were mounted on a SAS 4100 stereotactic device (ASI Instruments Inc.) (Figure 4).

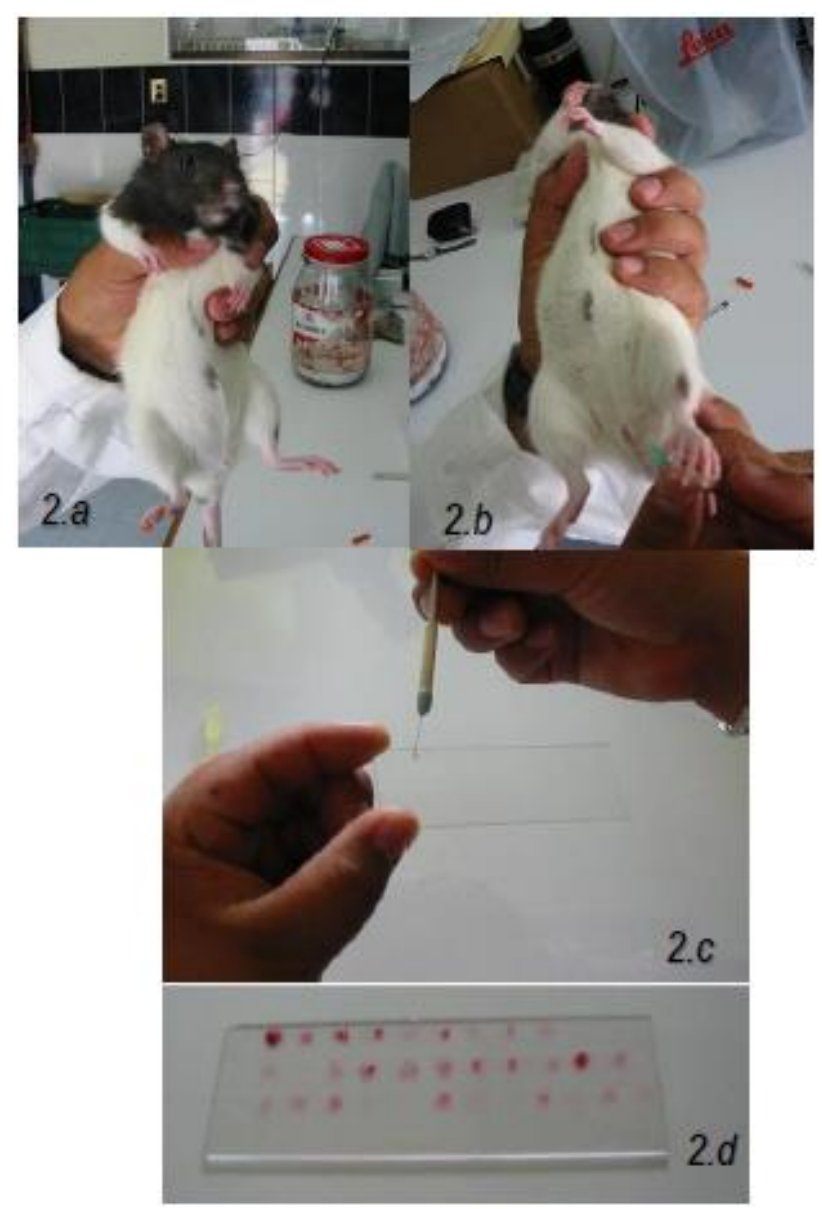

Figure 2 Subjection of the adult rats used in the experiments to obtain samples of vaginal epithelial cells and perform the estrous cycle recording (2.a and 2.b). The sample of cells is obtained with a stainless steel handle that is gently rubbed into the skin of the vagina (2.b and 2.c). The samples are placed on glass slides (smears) and allowed to dry at room temperature before they are stained by the hematoxylin-eosin technique (2.d) 


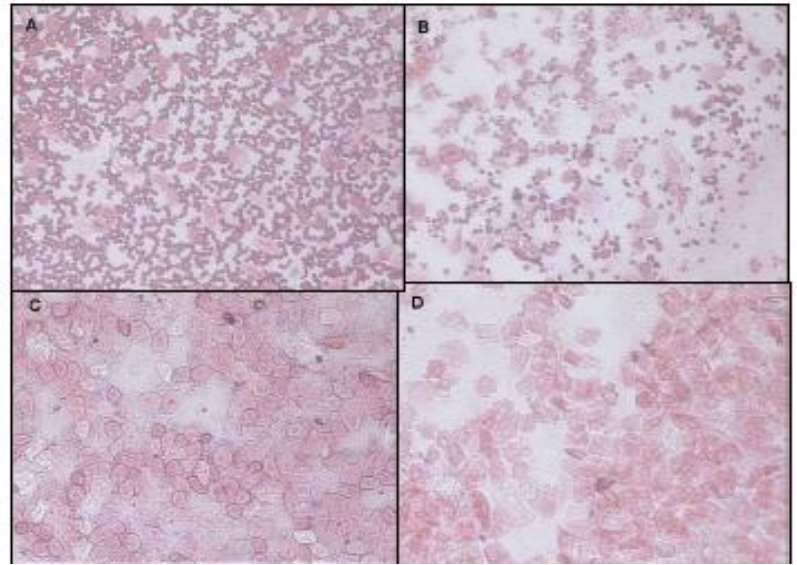

Figure 3 Characterization of the estrous cycle in an adult rat estimated by the appearance of vaginal Cytology A and B) Right, it is distinguished by the relatively high presence of leukocytes, few cubic epithelial cells with well-defined nuclei and some cells of defoliation of the vaginal epithelium; C) Proestro, is distinguished by the predominance of cubic epithelial cells with well-defined nuclei, some defoliation cells but virtual absence of leukocytes; D) Estrol, is distinguished by the abundant presence of nucleus-free cells - cornified - product of the defoliation of the vaginal epithelium, few epithelial cells with well-defined nuclei and occasionally some leukocytes.

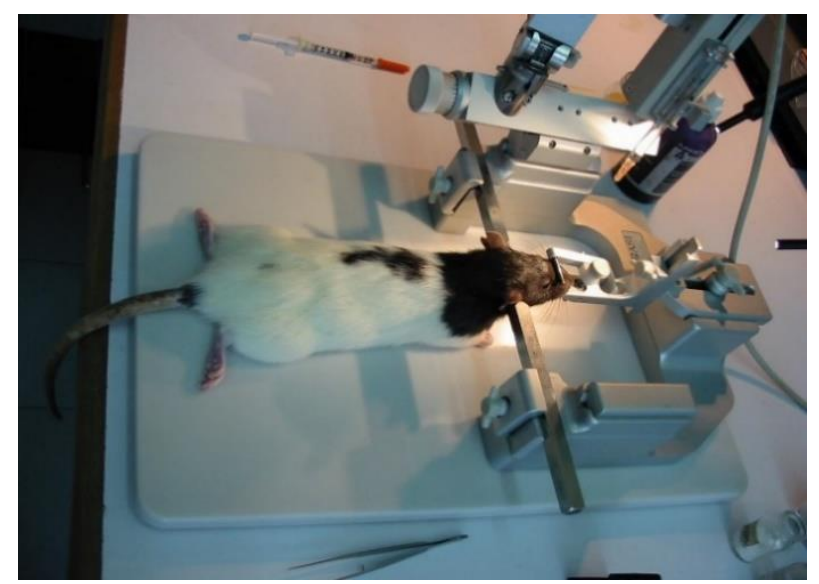

Figure 4 Mounting the animal on a standard stereotactic device. The animal remains attached to the ear bars by the auditory meatus and the muzzle by the bar of the incisors

At 13:00 on the day of estrus, the experimental groups of cyclic animals were treated as follows:

Each animal was shaved the skin of the head and a $1 \mathrm{~cm}$ long incision was made on the scalp with a scalpel.

The muscle layers of the skull were removed by scraping with fine-pointed tweezers. The wound was rubbed with gauze impregnated with $2 \%$ chlorhexidine antiseptic solution, followed by rubbing with $1 \%$ hydrogen peroxide solution in order to cauterize the blood vessels, to locate the anterior (bregma) and posterior (lambda) bone commissures ) of the skull and mark the stereotactic coordinates.

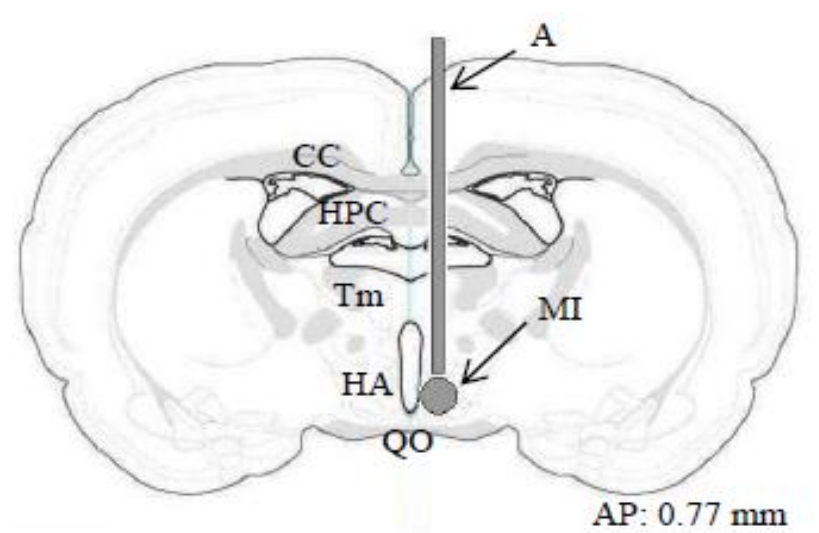

Figure 5 Coronal section of the brain of the adult rat showing the site of the unilateral or bilateral microinjection (MI) of haloperidol. The needle (A) of the microinjector passed through the thalamus and was placed just above the anterior hypothalamus. CC: cerebral cortex; HPC: hippocampus; Tm: thalamus; QO: optical chiasma; HA: anterior hypothalamus (Modified from the Stereotactic Atlas of Paxinos \& Watson, 1998)

The calculation of the coordinates for the realization of the microinjections was made based on the atlas of Paxinos and Watson (1998): Antero-Posterior $=+0.77 \mathrm{~mm}$; Lateral $= \pm 0.05$ $\mathrm{mm}$, with respect to the lambda commissure (Figure 5).

Once the Antero-Posterior and Lateral coordinates were located, the right and / or left side of the skull was perforated with Foredom 73B (Foredom Electric Co.) surgical drill and a stainless steel trepan (Figure 6).

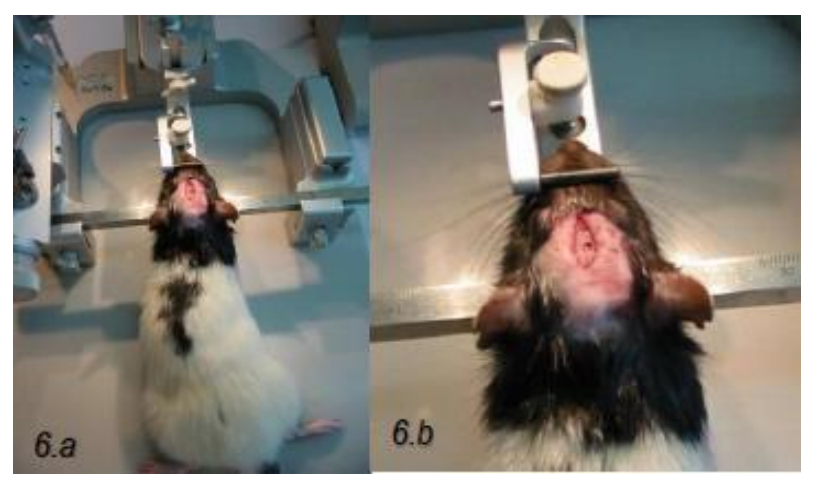

Figure 6. 6.a) Image showing the incision on the scalp of the animals and the location of the trepan. 6.b) When the meninges were exposed, the dura was cut in a cross so that the needle of the microinjector freely enters the brain of the animal

\section{Microinjection technique}

Once the trepane was performed, the meninges were visualized; The dura was cut crosswise and the microinjector needle (hypodermic needle No. 25; $0.05 \mathrm{~mm}$ internal diameter) was inserted connected to a nanomolar perfusion pump (Model 310; Steolting Co.) to the Vertical coordinate $=-0.72$, microinjection site (Figures 5 and 7).

MORÁN-PERALES, José Luis, SÁNCHEZ-GARCÍA, Octavio, GARCÍASUÁSTEGUI, Wendy Argelia and HANDAL-SILVA, Anabella. Effects of stereotactic surgery on the anterior hypothalamus (HA) on the estrous cycle: role stereotactic surgery on the anterior hypothalamus (HA) on the estrous cycle: role
of the dopaminergic system in spontaneous ovulation in the rat. ECORFAN of the dopaminergic system in spo 
Each animal received an intracerebral microinjection of $1 \mu \mathrm{L}$ of haloperidol solution $(15 \mu \mathrm{g} / \mu \mathrm{L} ; 5 \mu \mathrm{g} / \mathrm{min})$ in dimethylsulfoxide (DMSO) on the right, left or both sides of the anterior hypothalamus. As a control group, cyclic animals were used to which a unilateral microinjection of $1 \mu \mathrm{L}$ of pure DMSO $(0.33 \mu \mathrm{L} /$ min) was applied. The total time of each microinjection covered a period of six minutes: three minutes of infusion followed by three minutes of rest, before removing the needle from the microinjector. All animals received a dose of 8000 units of penicillin i.m. during the three days following stereotactic surgery (Figure 8).

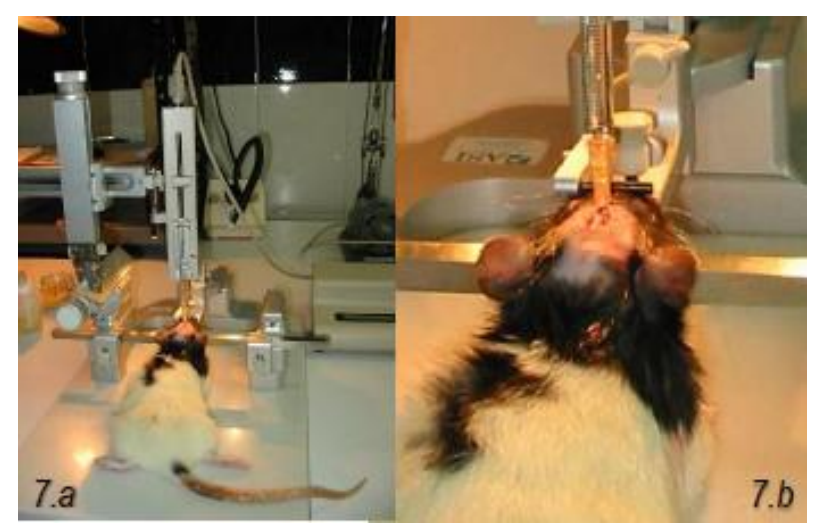

Figure 7. 7.a) Image showing the way in which the microinjection was performed by means of the nanomolar infusion pump mounted on the stereotactic apparatus. 7.b) The needle of the microinjector freely crosses the cerebral cortex and the thalamus of the animal until it reaches the anterior hypothalamus.

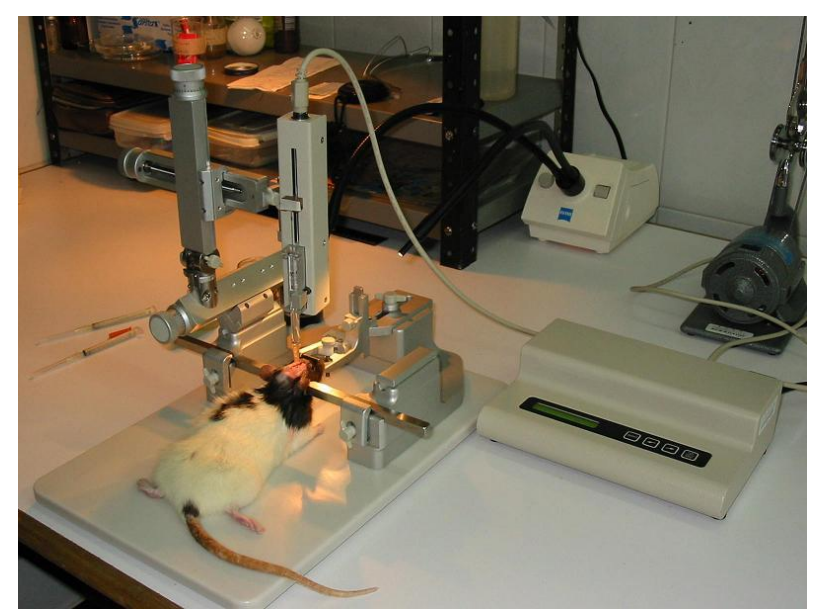

Figure 8. Photograph showing the equipment used to perform intracerebral microinjection of the haloperidol solution dissolved in dimethylsulfoxide in the anterior hypothalamus

\section{Euthanasia and General Autopsy}

The day after the unilateral bilateral injection, the vaginal smears were resumed and all animals were sacrificed between 09: 00-10: $00 \mathrm{~h}$ of the next vaginal estrus, preceded by proestrus (euthanasia was performed after a complete estrous cycle).

As a control group, cyclic animals were used that were not subjected to any surgical manipulation or experimental treatment (intact animals) and were sacrificed in the morning of estrus after four consecutive four-day estrous cycles.

\section{Data analysis}

With the data from the estrous cycle record, the relative duration of the estrous cycle was estimated and the rate of animals that presented a Short Estral Cycle (TCEC: from 4 to 6 days) or Long (TCEL: greater than 8 days) was estimated.:

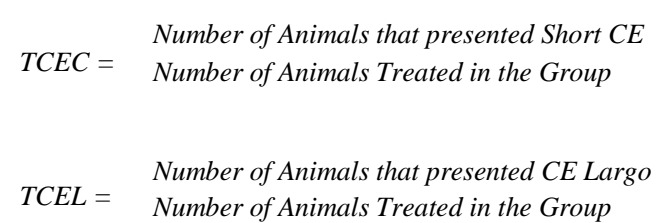

All animals were sacrificed between 09:00 and 10:00 in the morning of the next vaginal estrus in a carbon dioxide chamber.

At autopsy, the uterine tubes were dissected where the presence of oocytes was sought, which in their case were counted on a Stemi 2000-C stereomicroscope (Zeiss Co.). In those cases in which no fresh oocytes were observed, the ovaries were fixed in böuin solution for 24 hours and then progressively dehydrated in $70 \%$ ethanol, $96 \%$ ethanol and $100 \%$ ethanol (periods of 3 to 24,3 and 3 hours respectively), to then place them in 2 chloroform changes (periods of 24 and 3 hours, respectively) and finally included in paraffin blocks; they were cut in series at $10 \mu \mathrm{m}$ thick and colored according to the hematoxylin-eosin technique (Luna, 1975) and the thorough count of the fresh luteal bodies or healthy pre-follicle follicles was carried out, depending on the case. The ovaries and uterus were also dissected, and weighed on a $0.1 \mathrm{mg}$ precision balance (Scientech SP-250; Scientech Co.). 
The weight of the organs was expressed in milligrams per 100 grams of body weight ( $\mathrm{mg}$ / $100 \mathrm{~g}$ weight). The presence or absence of extravasation fluid in the uterine lumen was recorded from the uterus to estimate the rate of distended uterus (TUD) as an index of estrogen or progesterone secretion (Sánchez \& Domínguez, 1995):

\section{$\mathrm{TUD}=\frac{\text { Number of Animals with Uterus Distant }}{\text { Number of Animals Treated in the Group }}$}

The brains of all animals with cerebral microinjection were fixed in $10 \%$ formalin solution for $48 \mathrm{~h}$ and then cut in the frontal plane at $40 \mu \mathrm{m}$ thickness. These cuts were mounted in $2 \%$ jelly and then stained with $0.1 \%$ cresyl violet in order to locate the correct microinjection site (Luna, 1975) (Figure 9).

\section{Statistic analysis}

The TCEC, TCEL and TUD data were analyzed with Fisher's Exact Probability test. Data on the number of oocytes released and the days of the estrous cycle were analyzed by the KruskallWallis test, followed by the Dunn multiple comparison test or with Mann-Whitney U. The relative weights of the ovaries and uterus were analyzed with simple ANDEVA followed by the Tukey-Kramer multiple comparisons test or with Student's t test, as appropriate. In all tests, those differences in which the probability is equal to or less than 5\% were accepted as significant.

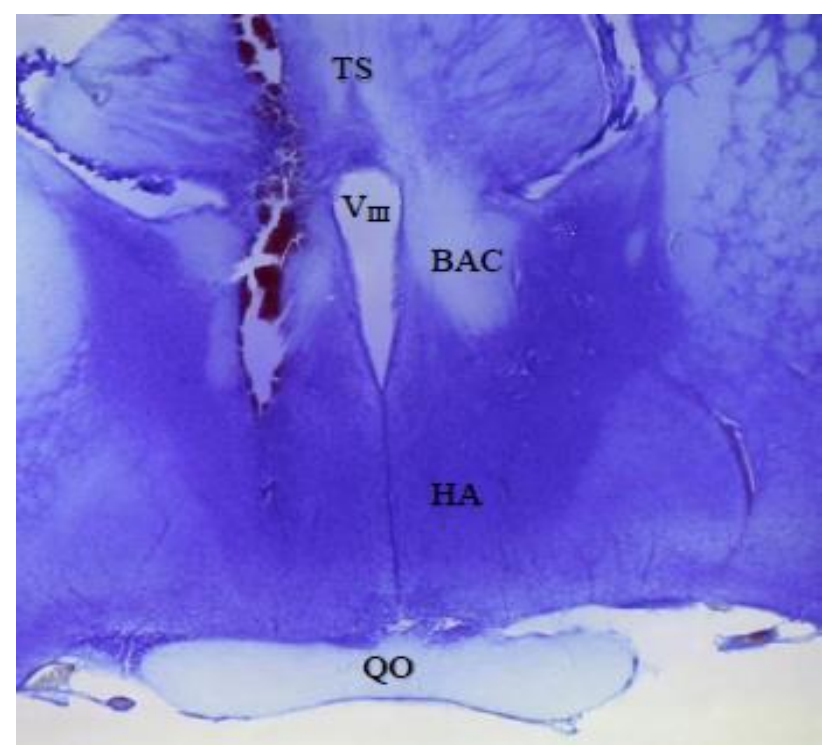

Figure 9 Coronal section of the suprachiasmatic area of the brain of the adult rat showing the area of microinjection with the haloperidol solution on the right side of the anterior hypothalamus. TS: triangular septal nucleus; BAC: bed nucleus of the previous commissure; VIII: third ventricle; HA: anterior hypothalamus; QO: optical chiasma.

\section{Results \\ Effects of Stereotactic Surgery on the Estral Cycle}

Surgical manipulation to perform bi-or unilateral microinjection in the anterior hypothalamus affected the animal's estrous cycle, since of the total of the animals that underwent stereotactic surgery $58 \%(80 / 139)$ of them significantly lengthened the cycle (Figure 10).

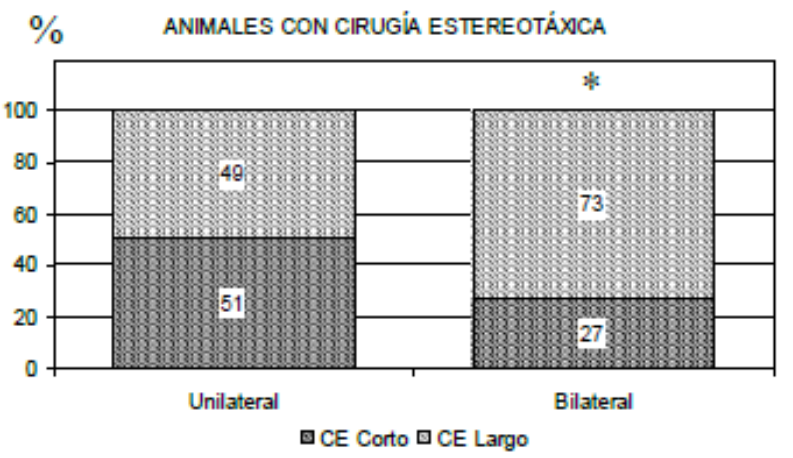

Figure 10 Percentage of animals undergoing stereotactic surgery that presented a short (CE) estrous cycle (Average Duration: $4.6 \pm 0.1$ days) or long (Average Duration: 13.6 $\pm 1.2)$

Compared to the group of intact animals (absolute control), stereotactic surgery performed on one side of the animals' brains, which before the intervention fulfilled at least three consecutive four-day estrous cycles, can cause elongation. of the estrous cycle significantly (43/88). But if brain surgery is performed on both sides of the brain, the probability that the estrous cycle will be prolonged is greater $(37 / 51)$.

That is, when the effect of bilateral brain surgery was analyzed compared to unilateral, it resulted in that $73 \%$ of animals with surgical manipulation in both cerebral hemispheres had an estrous cycle greater than 8 days compared to $49 \%$ of the animals with unilateral stereotactic surgery (Figure 11). 


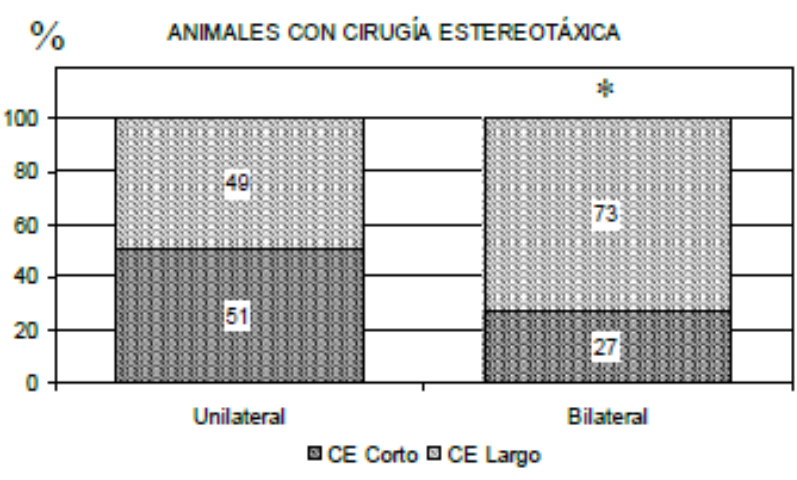

Figure 11 Comparison of the percentages of animals undergoing unilateral or bilateral stereotactic surgery in the brain of animals that presented a short (CE) estrous cycle (Average Duration: $4.6 \pm 0.1$ days) or long (Average Duration: $13.6 \pm 1.2)(* \mathrm{p}<0.01$ compared to unilateral stereotactic surgery; Fisher's Exact Probability test)

These results indicate that surgical manipulation in both hemispheres induces more likely the increase in the duration of the estrous cycle than manipulation on only one side of the brain (Table 1).

\begin{tabular}{|c|c|c|c|c|}
\hline Group & TCEC (\%) & $\begin{array}{l}\text { DCE } \\
\text { (days) }\end{array}$ & $\begin{array}{l}\text { TCEL } \\
(\%)\end{array}$ & $\begin{array}{c}\text { DCE } \\
\text { (days) }\end{array}$ \\
\hline $\begin{array}{l}\text { Absolute } \\
\text { Control }\end{array}$ & $\begin{array}{r}26 / 26 \\
(100 \%) \\
\end{array}$ & $4.0 \pm 0.0$ & $\begin{array}{r}0 / 26 \\
(0 \%) \\
\end{array}$ & \\
\hline \multicolumn{5}{|l|}{ MI-False } \\
\hline HA-Right & $\begin{array}{r}7 / 17 \\
(41 \%) \\
\end{array}$ & $4.4 \pm 0.2$ & $\begin{array}{r}10 / 17 \\
(59 \%) \\
\end{array}$ & $13.3 \pm 0.3$ \\
\hline HA-Left & $\begin{array}{r}8 / 16 \\
(50 \%) \\
\end{array}$ & $5.0 \pm 0.3$ & $\begin{array}{r}8 / 16 \\
(50 \%) \\
\end{array}$ & $13.3 \pm 0.5$ \\
\hline $\begin{array}{l}\text { HA- } \\
\text { Bilateral }\end{array}$ & $\begin{array}{r}11 / 23 \\
(47 \%) \\
\end{array}$ & $4.0 \pm 0.1$ & $\begin{array}{r}12 / 23 \\
(53 \%) \\
\end{array}$ & $14.0 \pm 0.6$ \\
\hline \multicolumn{5}{|l|}{ MI-Dmso } \\
\hline HA-Right & $\begin{array}{r}5 / 13 \\
(38 \%) \\
\end{array}$ & $4.5 \pm 0.3$ & $\begin{array}{r}8 / 13 \\
(62 \%) \\
\end{array}$ & $14.2 \pm 1.3$ \\
\hline HA-Left & $\begin{array}{r}8 / 11 \\
(72 \%) \\
\end{array}$ & $5.0 \pm 0.6$ & $\begin{array}{r}3 / 11 \\
(28 \%) \\
\end{array}$ & $12.0 \pm 2.3$ \\
\hline $\begin{array}{l}\text { HA- } \\
\text { Bilateral }\end{array}$ & $\begin{array}{r}1 / 11 \\
(10 \%) *, \beta \\
\end{array}$ & $5.0 \pm 0.6$ & $\begin{array}{r}10 / 11 \\
(90 \%) *, \beta \\
\end{array}$ & $13.2 \pm 0.4$ \\
\hline \multicolumn{5}{|l|}{ MI-HLP } \\
\hline HA-Right & $\begin{array}{r}10 / 17 \\
(58 \%) \\
\end{array}$ & $4.4 \pm 0.2$ & $\begin{array}{r}7 / 17 \\
(42 \%) \\
\end{array}$ & $13.4 \pm 0.7$ \\
\hline HA-Left & $\begin{array}{r}7 / 14 \\
(50 \%) \\
\end{array}$ & $4.4 \pm 0.2$ & $\begin{array}{r}7 / 14 \\
(50 \%) \\
\end{array}$ & $13.4 \pm 0.6$ \\
\hline $\begin{array}{l}\text { HA- } \\
\text { Bilateral }\end{array}$ & $\begin{array}{r}2 / 17 \\
(11 \%) *, \alpha \\
\end{array}$ & $6.0 \pm 0.0$ & $\begin{array}{r}15 / 17 \\
(89 \%) *, \alpha \\
\end{array}$ & $14.2 \pm 0.5$ \\
\hline \multicolumn{5}{|c|}{$\begin{array}{l}* \mathrm{p}<0.05 \text { compared to all groups with false microinjection; } \alpha \\
\mathrm{p}<0.05 \text { compared to unilateral microinjections in HA of the } \\
\text { same group; } \beta \mathrm{p}<0.01 \text { compared to microinjection in HA-Left } \\
\text { of the same group (Fisher's Exact Probability Tests). }\end{array}$} \\
\hline
\end{tabular}

Table 1 Short and long-term (TCEL) and half-day (TCEL) estrous cycle rates \pm eem of the estrous cycle duration (DCE) in animals undergoing intracerebral microinjection (MI) of a solution of haloperidol (HLP; $10 \mu \mathrm{g} / \mu \mathrm{L} ; 0.2 \mu \mathrm{g}$ $/ \mathrm{min}$ ) in dimethylsulfoxide (Dmso) on the right, left side or on both sides of the anterior hypothalamus (HA) at 1:00 p.m. on the day of estrus. False MI consisted of needle insertion without touching the HA

\section{Effects of Intra-Cerebral Microinjection on the Duration of the Estral Cycle}

The global analysis of the groups indicated that the average duration of a Short Estral Cycle was $4.6 \pm 0.1$ days $(\mathrm{N}=59)$, while the average duration of a Long Estral Cycle was $13.6 \pm 0.2$ $(\mathrm{N}=80)$. In Table 1 it can be seen that there were no differences in the cycle duration between the groups of animals with Short Estral Cycle or with Long Estral Cycle.

In the control groups with False Microinjection no differences were observed in the rates of animals that presented a Short Estral Cycle or a Long Estral Cycle. Neither were differences observed in the groups with Unilateral Microinjection with DMSO or with haloperidol with respect to the groups with False Microinjection (Table 1).

On the other hand, in Table 1 it can be observed that in the groups with Bilateral Microinjection with DMSO or with haloperidol it caused that the rate of animals that presented Long Estral Cycle was significantly higher compared with the groups with False or Unilateral Microinjections (Bilateral Microinjection: 25 / 28 vs. False Microinjection: 30/56 or Unilateral Microinjection: 25/54, p $<0.001$; Fisher's Exact Probability Test).

Since the surgical manipulation affected the duration of the estrous cycle, in the analysis of the data described below it was decided to group the data in animals with Short Estral Cycle (Observed Range: from 4 to 6 days of duration) and in animals with Long Estral Cycle (Observed Range: 8 to 17 days long).

\section{Effects of Haloperidol Brain Microinjection on the Ovulation of Animals with Short Estral Cycle}

The global analysis of the effects of surgical manipulations in animals that presented a Short Estral Cycle, allow to visualize the tendency to reduce ovulation with respect to the group of intact animals (Absolute Control $(\mathrm{N}=26): 11.7$ \pm 0.3 vs. False Microinjections and with DMSO $(\mathrm{N}=40): 10.8 \pm 0.5$ or Microinjections with Haloperidol $(\mathrm{N}=19)$ : $9.7 \pm 0.9 ; \mathrm{p}<0.05$; Kruskall-Wallis followed by Dunn's multiple comparisons test) (Figure 12). 


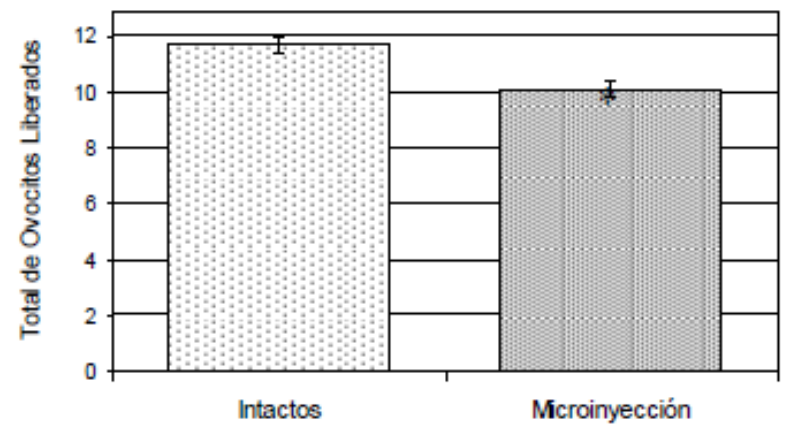

Figure 12 Mean \pm E.E. of the number of oocytes released by the ovaries of intact animals and to which they were given an intracerebral microinjection of a solution of haloperidol in dimethylsulfoxide $(10 \mu \mathrm{g} / \mu \mathrm{L} ; 0.2 \mu \mathrm{g} / \mathrm{min})$ or a false microinjection on the right, left or right side both sides of the anterior hypothalamus at 1:00 p.m. on estrus day $(* \mathrm{p}<0.01$ with intact animal groups; Mann-Whitney $\mathrm{U}$ test)

Compared to the group of intact animals, Unilateral False Microinjection induced the drop in the number of oocytes released by the left ovary (Absolute Control $(\mathrm{N}=26)$ : $6.2 \pm 0.3$ vs. Unilateral False Microinjection ( $\mathrm{N}=15): 2.8 \pm$ $0.5 ; \mathrm{p}<0.005$; Mann-Whitney U) without modifying those of the right ovary (Table 2).

\begin{tabular}{|c|c|c|c|}
\hline \multicolumn{4}{|c|}{ Animals That Presented Short Estral Cycle } \\
\hline Group & $\begin{array}{l}\text { NOL } \quad \text { Left } \\
\text { Side }\end{array}$ & \begin{tabular}{|l|} 
NOL Side \\
Right
\end{tabular} & NOL Totals \\
\hline$(\mathrm{N})$ & $6.2 \pm 0.3$ & $5.5 \pm 0.2$ & $11.7 \pm 0.3$ \\
\hline \multicolumn{4}{|l|}{$\begin{array}{l}\text { Absolute Control } \\
\text { (26) }\end{array}$} \\
\hline MI-False & $3.9 \pm 0.9 *$ & $5.1 \pm 0.7$ & $9.0 \pm 1.3$ \\
\hline HA-Law (7) & $1.9 \pm 0.4 *{ }^{\alpha}{ }^{\alpha}$ & $5.9 \pm 0.8$ & $7.8 \pm 0.8 *$ \\
\hline HA-Left (8) & $6.0 \pm 0.6$ & $5.1 \pm 0.7$ & $12.1 \pm 0.7$ \\
\hline \multicolumn{4}{|l|}{$\begin{array}{l}\text { HA-Bilateral } \\
(11)\end{array}$} \\
\hline MI-Dmso & $5.2 \pm 0.8$ & $5.6 \pm 0.5$ & $10.8 \pm 0.9$ \\
\hline HA-Right (5) & $4.5 \pm 0.6^{\alpha}$ & $6.5 \pm 0.6$ & $11.0 \pm 0.6^{\delta}$ \\
\hline HA-Left (8) & 4 & 5 & \\
\hline \multicolumn{4}{|l|}{ HA-Bilateral (1) } \\
\hline MI-HLP & $3.7 \pm 0.4 *,^{\alpha}$ & $6.0 \pm 0.4$ & $9.7 \pm 0.5^{\beta}$ \\
\hline HA-Right (10) & $5.9 \pm 0.7^{\alpha}$ & $3.9 \pm 0.5$ & $9.8 \pm 0.6^{\beta}$ \\
\hline HA-Left (7) & $(2,4)$ & $(7,6)$ & $(9,10)$ \\
\hline \multicolumn{4}{|c|}{$\begin{array}{l}\text { * p }<0.05 \text { compared to the Absolute Control and Bilateral False } \\
\text { Microinjection (Kruskall-Wallis test followed by Dunn's } \\
\text { multiple comparisons test); } \alpha \mathrm{p}<0.005 \text { compared to the } \\
\text { contralateral ovary; } \beta \mathrm{p}<0.05 \text { compared to the Absolute } \\
\text { Control; } \delta \mathrm{p}<0.05 \text { compared to its group with False } \\
\text { Microinjection (Tests with Mann-Whitney U). }\end{array}$} \\
\hline
\end{tabular}

Table 2 Mean \pm e.e.m. of the number of oocytes released (NOL) by the ovaries of the animals that underwent an intracerebral microinjection (MI) of a haloperidol solution (HLP) in dimethylsulfoxide (Dmso) $(10 \mu \mathrm{g} / \mu \mathrm{L} ; 0.2 \mu \mathrm{g} /$ $\mathrm{min})$ in the right, left or both sides of the anterior hypothalamus (HA) at 1:00 p.m. on the day of estrus. All animals were sacrificed on the morning of the next vaginal estrus after microinjection and after presenting a shortterm estrous cycle (4 to 6 days). False MI consisted of needle insertion without touching the HA
This drop is such that it is reflected in the total number of oocytes released in the groups with False Microinjection on the right or left side of the anterior hypothalamus (Absolute Control $(\mathrm{N}=26): 11.7 \pm 0.3$ vs. Unilateral False Microinjection $(\mathrm{N}=15)$ : $8.3 \pm 0.7 ; \mathrm{p}<0.01$; Mann-Whitney U). This did not occur in the groups with False Microinjection on both sides of the anterior hypothalamus (Figure 13). There was a similar trend in the groups with Unilateral Microinjection with DMSO, in which the left ovary also decreased its ovulatory quota (Absolute Control $(\mathrm{N}=26): 6.2 \pm 0.3$ vs. DMSO Unilateral Microinjection: $4.8 \pm 0.5(\mathrm{~N}=13) ; \mathrm{p}$ $<0.05$; Mann-Whitney U) but not reflected in the total number of oocytes (Table 2) (Figure 13).

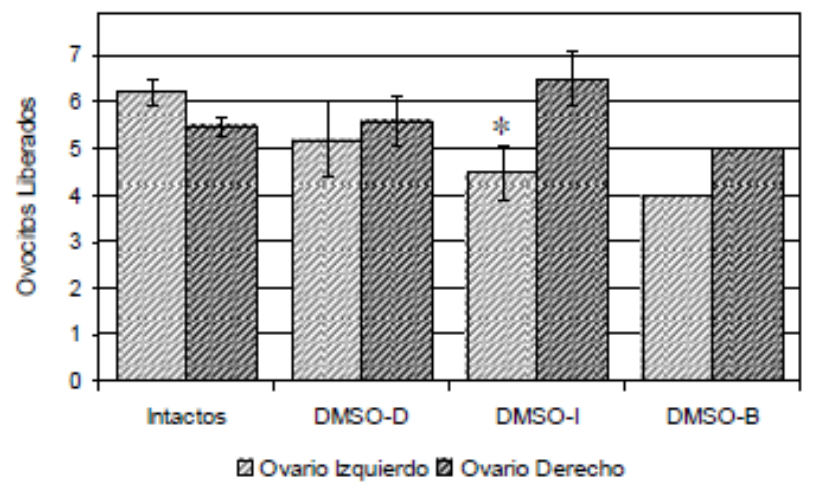

Figure 13 Mean \pm E.E. of the number of oocytes released by the ovaries of animals that underwent intracerebral microinjection with dimethylsulfoxide (DMSO) $(1 \mu \mathrm{L} ; 0.2$ $\mu \mathrm{L} / \mathrm{min}$ ) on the right (-D), left (-I) side or both sides (-B) of the anterior hypothalamus at 1:00 p.m. on the day of estrus $(* p<0.05$ compared to the contralateral ovary and with the same ovary from the group of intact animals; Kruskall-Wallis test followed by the comparison test Dunn multiple)

Unilateral Microinjection with Haloperidol induced changes in ovulation of the ovaries that depended on the side on which dopamine receptors were blocked. Microinjection of the dopamine antagonist on the right side of the anterior hypothalamus inhibited ovulation of the left ovary, while microinjection of the drug on the left side inhibited that of the right. Both drops tend to decrease the total oocyte quota (Absolute Control $(\mathrm{N}=26): 11.7 \pm 0.3$ vs. Unilateral Microinjections with Haloperidol $(\mathrm{N}=17)$ : 9.8 $\pm 0.4 ; \mathrm{p}<0.05$; $\mathrm{U}$ of Mann-Whitney) (Table 2) (Figure 14). There were no significant changes in the weight of the ovaries in the groups of animals that presented Short Estral Cycle. However, False or DMSO Unilateral Microinjection on the left side of the anterior hypothalamus tend to increase the weight of the uterus (Absolute Control $(\mathrm{N}=26)$ :

MORÁN-PERALES, José Luis, SÁNCHEZ-GARCÍA, Octavio, GARCÍASUÁSTEGUI, Wendy Argelia and HANDAL-SILVA, Anabella. Effects of stereotactic surgery on the anterior hypothalamus (HA) on the estrous cycle: stereotactic surgery on the anterior hypothalamus (HA) on the estrous cycle: role
of the dopaminergic system in spontaneous ovulation in the rat. ECORFAN Journal-Republic of Guatemala. 2019 
$182 \pm 8 \mathrm{mg} / 100 \mathrm{~g}$ weight or Right Side Microinjections $(\mathrm{N}=12): 188 \pm 10 \mathrm{mg} / 100 \mathrm{~g}$ weight vs. Microinjection Left Side $(\mathrm{N}=16)$ : $223 \pm 11 \mathrm{mg} / 100 \mathrm{~g}$ weight, $\mathrm{p}<0.05$; Tests with Student's t), which correlated with the Uterus Distenced Rate In these groups. False or DMSO Bilateral Microinjections, like Haloperidol Microinjections, did not modify the weight of the uterus (Table 3).

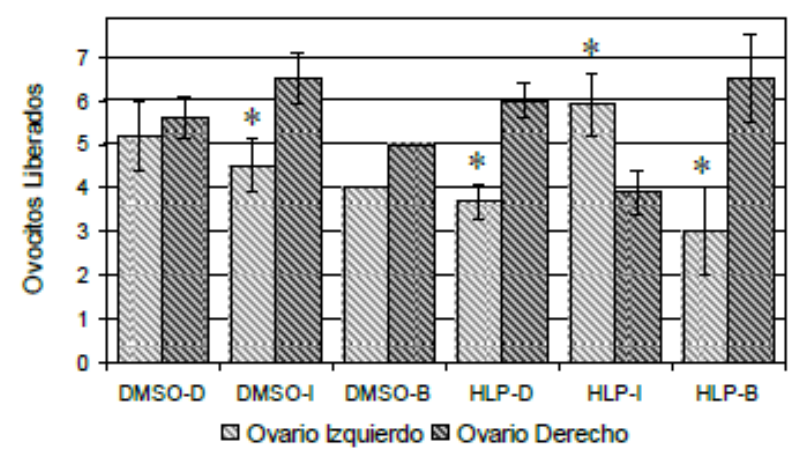

Figure 14. Mean \pm E.E. of the number of oocytes released by the ovaries of animals that underwent intracerebral microinjection with haloperidol (HLP) $(15 \mu \mathrm{g} / \mu \mathrm{L} ; 3 \mu \mathrm{g} /$ min) or with DMSO (vehicle; $1 \mu \mathrm{L} ; 0.2 \mu \mathrm{g} / \mathrm{min}$ ) in the right (-D), left (-I) or both sides (-B) of the anterior hypothalamus at 1:00 p.m. on the day of estrus $(* \mathrm{p}<0.05$ with the contralateral ovary Kruskall-Wallis test followed by Dunn's multiple comparison test)

\begin{tabular}{|c|c|c|c|c|c|}
\hline \multicolumn{6}{|c|}{ Animals That Presented Short Estral Cycle } \\
\hline $\begin{array}{l}\text { Group } \\
(\mathrm{N})\end{array}$ & OI & OD & MO & Uterus & TUD \\
\hline $\begin{array}{l}\text { Absolute } \\
\text { Control } \\
(26)\end{array}$ & $12.9 \pm 0.5$ & $12.8 \pm 0.6$ & $25.7 \pm 0.9$ & $182 \pm 8$ & $5 / 26$ \\
\hline \multicolumn{6}{|l|}{ MI-False } \\
\hline HA-D (7) & $12.8 \pm 0.8$ & $11.9 \pm 0.6$ & $24.7 \pm 1.4$ & $177 \pm 12$ & $1 / 7$ \\
\hline HA-I (8) & $12.9 \pm 1.3$ & $14.6 \pm 1.6$ & $27.5 \pm 2.7$ & $223 \pm 16$ & $6 / 8$ \\
\hline $\begin{array}{l}\text { HA-B } \\
(11)\end{array}$ & $11.6 \pm 0.7$ & $11.5 \pm 0.5$ & $23.1 \pm 1.0$ & $177 \pm 9$ & $3 / 11$ \\
\hline \multicolumn{6}{|l|}{$\begin{array}{l}\text { MI- } \\
\text { Dmso }\end{array}$} \\
\hline HA-D (5) & $11.3 \pm 0.9$ & $11.4 \pm 0.7$ & \begin{tabular}{|l|}
$22.7 \pm 1.5$ \\
\end{tabular} & $203 \pm 15$ & $1 / 5$ \\
\hline HA-I (8) & $11.3 \pm 0.3$ & $11.4 \pm 0.5$ & $22.7 \pm 0.7$ & $222 \pm 15$ & $5 / 8 *$ \\
\hline HA-B (1) & $(9.1)$ & $(10.4)$ & $(19.5)$ & $(187)$ & $0 / 1$ \\
\hline \multicolumn{6}{|l|}{ MI-HLP } \\
\hline $\begin{array}{l}\text { HA-D } \\
(10)\end{array}$ & $13.7 \pm 0.6$ & $12.9 \pm 0.7$ & $26.6 \pm 1.1$ & $179 \pm 8$ & $2 / 10$ \\
\hline HA-I (7) & $12.9 \pm 0 .-8$ & $12.4 \pm 1.0$ & $25.3 \pm 1.7$ & $188 \pm 13$ & $1 / 7$ \\
\hline HA-B (2) & $(12.1,11.3)$ & $(14.1,12.8)$ & $(26.2,24.1)$ & $(244,182)$ & $1 / 2$ \\
\hline
\end{tabular}

Table 3 Mean \pm e.e.m. of the relative weight of the left ovary (OI), right (OD) or ovarian mass (MO) and uterus (mg / 100g body weight) and distended uterus rate (TUD) of animals that underwent Intracerebral microinjection (MI) of a solution of haloperidol (HLP) in dimethylsulfoxide (Dmso; $10 \mu \mathrm{g} / \mu \mathrm{L} ; 0.2 \mu \mathrm{g} / \mathrm{min}$ ) on the right (-D), left (-I) or both sides (-B) of the anterior hypothalamus (HA) at 1:00 p.m. on the day of estrus. All animals were sacrificed on the morning of the next vaginal estrus after microinjection and after presenting a shortterm estrous cycle (4 to 6 days). False MI consisted of needle insertion without touching the HA

\section{Effects of Haloperidol Brain Microinjection on the Ovulation of Animals with Long Estral Cycle}

False Microinjections did not modify the individual ovulation of each ovary in animals that had a Long Estral Cycle, but a relative drop in total ovulation was observed in the group with Bilateral False Microinjection (Table 4).

Bilateral Microinjection of DMSO reduced the number of oocytes released by the left ovary, but increased it in those released by the right ovary. Compared to the group with Bilateral False Microinjection, DMSO Bilateral Microinjection tends to increase the total number of oocytes released (Table 4) (Figure 15).

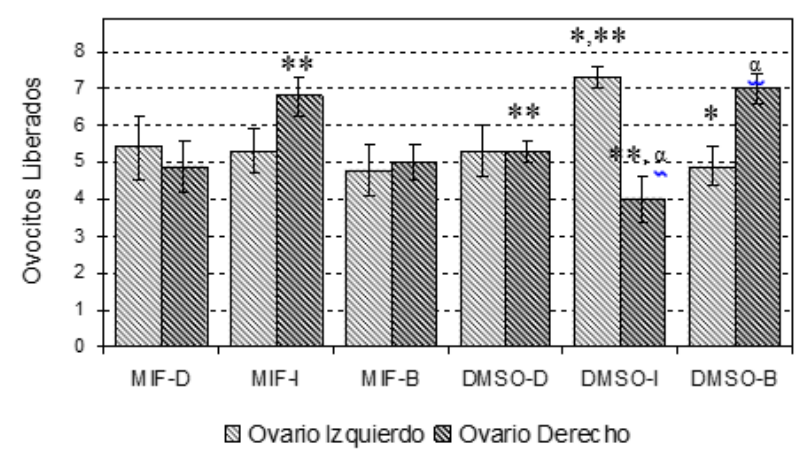

Figure 15. Mean \pm E.E. of the number of oocytes released by the ovaries of the animals who underwent a false intracerebral microinjection (MIF) or with DMSO (vehicle; $1 \mu \mathrm{L} ; 0.2 \mu \mathrm{g} / \mathrm{min}$ ) on the right (-D), left (-I) ) or on both sides (-B) of the anterior hypothalamus at 1:00 p.m. on the day of estrus $(* \mathrm{p}<0.05$ compared to the contralateral ovary; $* * \mathrm{p}<0.01$ compared to bilateral manipulation in the same group; $\square \mathrm{p}<0.05$ compared to your group with MIF (Mann-Whitney U test).

It was observed that the number of oocytes released by the left ovary tends to decrease and increase those of the right ovary in the groups with Unilateral Microinjection with Haloperidol (Left Ovary ( $\mathrm{N}=14)$ : $4.6 \pm 0.2$ vs. Right Ovary $(\mathrm{N}=14): 6.3 \pm 0.3, \mathrm{p}<0.001$; Mann-Whitney U test), unchanged in the group with Bilateral Microinjection of the drug (Table 4) (Figure 16).

No significant changes were observed in the weight of the ovaries or in the Uterus Dysted Rates among the groups of animals that presented the Long Estral Cycle (Table 5). 


\section{Discussion of results}

After stereotactic surgery, the probability that an animal with regular four-day estrous cycles loses the pattern of regularity in its subsequent cycles is very high, since $58 \%$ of cyclic animals undergoing brain surgery (80/139) significantly extend the next estrous cycle to an average of 14 days.

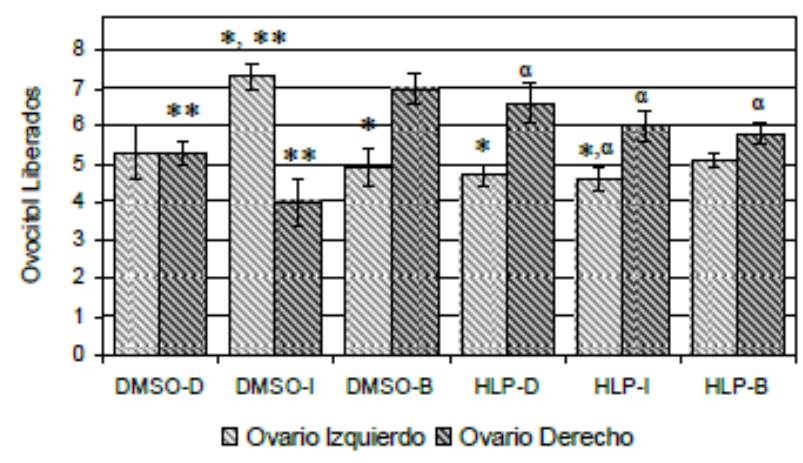

Figure 16 Mean \pm E.E. of the number of oocytes released by the ovaries of animals that underwent intracerebral microinjection with haloperidol (HLP) $(15 \mu \mathrm{g} / \mu \mathrm{L} ; 3 \mu \mathrm{g} /$ min) or with DMSO (vehicle; $1 \mu \mathrm{L} ; 0.2 \mu \mathrm{g} / \mathrm{min}$ ) in the right (-D), left (-I) or both sides (-B) of the anterior hypothalamus at 1:00 p.m. on the day of estrus $(* \mathrm{p}<0.05$ with the contralateral ovary; $* * \mathrm{p}<0.01$ compared to bilateral manipulation in the same group; $\square \mathrm{p}<0.05$ compared to its group with DMSO (Mann-Whitney U test)

The registration of vaginal smears in these animals showed that the entire cycle was characterized by the presence of leukocytes (vaginal right-handed) before observing the presence of the proestrus and vaginal estrus. This suggests that surgical manipulation is capable of significantly altering the neuroendocrine and endocrine mechanisms that regulate gonadotropin secretion and therefore the estrous cycle. It is feasible that the presence of the vaginal right-hand sign is a reflection of the secretion of prolactin capable of sustaining the progestogenic activity of the luteal bodies that for some reason do not return.

It is widely documented that prolactin maintains a relatively high secretion during the early stages of pseudopregnancy and pregnancy and prior to the formation of the placenta (Freeman, 1988). Prolactin indirectly inhibits the secretion of FSH and LH by prolonging the life of the corpus luteum (Smith et al, 1975 and 1976).
When estrogen concentrations have declined and remain relatively low, the increasing concentration of progesterone acts with a negative feedback effect on the anterior hypothalamus and inhibits the secretion of $\mathrm{GnRH}$ and thereby the secretion of gonadotropins is interrupted (Fink, 1979 and 1988 ; Fink et al, 1983). For years, it has been known that stress induces the sudden discharge of prolactin in the rat, accompanied by the suppression of the prevolvulatory peak of LH (Neill, 1970; Neill et al, 1971). This evidence is totally consistent with our observations, since more than half of the animals subject to stereotactic surgery lengthened the estrous cycle.

\begin{tabular}{|c|c|c|c|}
\hline \multicolumn{4}{|c|}{ Animals That Presented Long Estral Cycle } \\
\hline $\begin{array}{l}\text { Group } \\
\text { (N) }\end{array}$ & $\begin{array}{ll}\text { NOL } & \text { Left } \\
\text { Side } & \end{array}$ & $\begin{array}{l}\text { NOL Right } \\
\text { Side }\end{array}$ & NOL Totals \\
\hline $\begin{array}{l}\text { Absolute } \\
\text { Control (26) }\end{array}$ & $6.2 \pm 0.3$ & $5.5 \pm 0.2$ & $11.7 \pm 0.3$ \\
\hline \multicolumn{4}{|l|}{ MI-False } \\
\hline HA-Right (10) & $5.4 \pm 0.9$ & $4.9 \pm 0.7$ & $10.3 \pm 0.7$ \\
\hline HA-Left (8) & $5.3 \pm 0.6$ & $6.8 \pm 0.5^{\delta}$ & $12.1 \pm 0.6$ \\
\hline $\begin{array}{l}\text { HA-Bilateral } \\
\text { (12) }\end{array}$ & $4.8 \pm 0.7$ & $5.0 \pm 0.5$ & $9.8 \pm 0.4$ \\
\hline \multicolumn{4}{|l|}{ MI-Dmso } \\
\hline HA-Right (8) & $5.3 \pm 0.7$ & $5.3 \pm 0.3^{\delta}$ & $10.6 \pm 0.7$ \\
\hline HA-Left (3) & $7.3 \pm 0.3^{\beta}$ & $4.0 \pm 0.6^{\beta, \delta}$ & $11.3 \pm 0.7$ \\
\hline $\begin{array}{l}\text { HA-Bilateral } \\
(10)\end{array}$ & $4.9 \pm 0.5^{\alpha}$ & $7.0 \pm 0.4^{\beta}$ & $11.9 \pm 0.5$ \\
\hline \multicolumn{4}{|l|}{ MI-HLP } \\
\hline HA-Law (7) & $4.7 \pm 0.3^{\alpha}$ & $6.6 \pm 0.5$ & $11.3 \pm 0.5$ \\
\hline HA-Left (7) & $4.6 \pm 0.3^{\alpha}$ & $6.0 \pm 0.4$ & $10.6 \pm 0.6$ \\
\hline $\begin{array}{l}\text { HA-Bilateral } \\
(15)\end{array}$ & $5.1 \pm 0.2$ & $5.8 \pm 0.3$ & $10.9 \pm 0.3$ \\
\hline \multicolumn{4}{|c|}{$\begin{array}{l}* p<0.05 \text { compared to the Absolute Control (Kruskall-Wallis } \\
\text { test followed by Dunn's multiple comparisons test); ** } p<0.01 \\
\text { compared to the same group with DMSO and with } \\
\text { Haloperidol; } \alpha p<0.05 \text { compared to the contralateral ovary; } \\
\beta p<0.05 \text { compared to the other groups with microinjection in } \\
\text { HA on the same side; } \square p<0.05 \text { compared to bilateral } \\
\text { manipulation with the same treatment (Mann-Whitney U tests). }\end{array}$} \\
\hline
\end{tabular}

Table 4 Mean \pm e.e.m. of the number of oocytes released (NOL) by the ovaries of the animals that underwent an intracerebral microinjection (MI) of a solution of haloperidol (HLP) in dimethylsulfoxide (Dmso; 10 $\mu \mathrm{g} /$ $\mu \mathrm{L} ; 0.2 \mu \mathrm{g} / \mathrm{min}$ ) in the right side (-D), left (-I) or on both sides (-B) of the anterior hypothalamus (HA) at 1:00 p.m. on the day of estrus. All animals were sacrificed on the morning of the next vaginal estrus after microinjection and after presenting a prolonged estrous cycle of 12 to 17 days. False MI consisted of needle insertion without touching the HA 
It is also feasible that surgical stress helped increase the likelihood that the animal will lose the estrous cycle by inducing the discharge of glucocorticoids. It is a known fact that $\mathrm{CRH}$ produced in the hypothalamus directly stimulates the adenohypophyseal corticotrope and induces the release of ACTH and $\beta$ Endorphin, followed by the secretion of cortisol and corticosterone in the adrenal cortex (Arimura, 2000; Welsh \& Johnson, 1981)

CRH is rapidly released in response to a wide variety of stressors, but it is particularly important to note that CRH stimulates its own secretion in the hypothalamus by means of a mechanism for increasing regulation of a shortloop paracrine type. It is known that $\mathrm{CRH}$ interrupts the release of GHRH and $\mathrm{GnRH}$ (Arimura 2000; McCann et al, 1983) so it is feasible that the alteration of the estrous cycle is the reflection of the interruption of the hypothalamic signal that determines secretion of gonadotropins and changes in ovulation (Kamel \& Kubajak, 1987; Peppler \& Jacobs, 1976; Welsh \& Jonson, 1981). In addition, glucocorticoids are shown to be able to stimulate progesterone secretion in follicular cell cultures (Adshi et al, 1981).

\begin{tabular}{|l|l|l|l|l|l|}
\hline \multicolumn{7}{|c|}{ Animals That Presented Long Estral Cycle } \\
\hline Group & OI & OD & MO & Uterus & TUD \\
\hline (N) & $12.9 \pm 0.4$ & $12.8 \pm 0.5$ & $25.7 \pm 0.9$ & $182 \pm 8$ & $5 / 26$ \\
\hline $\begin{array}{l}\text { Absolute } \\
\text { Control (26) }\end{array}$ & & & & & \\
\hline MI-False & $14.5 \pm 0.9$ & $12.9 \pm 0.7$ & $27.4 \pm 1.5$ & $163 \pm 8$ & $1 / 10$ \\
\hline HA-D (10) & $12.7 \pm 1.2$ & $12.2 \pm 1.1$ & $24.9 \pm 2.0$ & $171 \pm 15$ & $2 / 8$ \\
\hline HA-I (8) & $13.2 \pm 0.8$ & $11.7 \pm 0.6$ & $24.9 \pm 0.9$ & $182 \pm 10$ & $1 / 12$ \\
\hline HA-B (12) & & & & & \\
\hline MI-Dmso & $11.9 \pm 0.4$ & $12.6 \pm 0.5$ & $24.5 \pm 0.7$ & $187 \pm 10$ & $4 / 8$ \\
\hline HA-D (8) & $11.1 \pm 1.4$ & $13.7 \pm 1.4$ & $24.8 \pm 1.6$ & $191 \pm 10$ & $2 / 3$ \\
\hline HA-I (3) & $11.4 \pm 0.6$ & $11.5 \pm 0.6$ & $22.9 \pm 1.0$ & $187 \pm 7$ & $4 / 10$ \\
\hline HA-B (10) & & & & & \\
\hline MI-HLP & $12.7 \pm 0.5$ & $13.7 \pm 0.9$ & $26.4 \pm 1.2$ & $189 \pm 14$ & $3 / 7$ \\
\hline HA-D (7) & $13.5 \pm 0.8$ & $13.7 \pm 0.7$ & $27.2 \pm 1.0$ & $177 \pm 14$ & $2 / 7$ \\
\hline HA-I (7) & $11.6 \pm 0.4$ & $12.2 \pm 0.5$ & $23.8 \pm 0.8$ & $167 \pm 9$ & $4 / 15$ \\
\hline
\end{tabular}

Table 5 Mean \pm e.e.m. of the relative weight of the right (OD), left (OI) ovaries, ovarian mass (MO) and uterus (mg / $100 \mathrm{~g}$ body weight) by animals that underwent microinjection (MI) of a dissolution of haloperidol (HLP) in dimethylsulfoxide (Dmso; $10 \mu \mathrm{g} / \mu \mathrm{L} ; 0.2 \mu \mathrm{g} / \mathrm{min}$ ) on the right (-D), left (-I) or on both sides (-B) of the anterior hypothalamus (HA) at 1:00 p.m. on the day of estrus. All animals were sacrificed on the morning of the next vaginal estrus after microinjection and after presenting a prolonged estrous cycle (12 to 17 days). False MI consisted of needle insertion without touching the HA
On the other hand, when the dopamine antagonist vehicle or drug was infiltrated directly on both sides of the anterior hypothalamus, significant differences were observed depending on whether the microinjection was performed on one or both sides of the hypothalamus, since the frequency at which they occurred estrous cycle of more than twelve days duration was significantly longer in animals with bilateral microinjection than in those with unilateral microinjection. It has been shown that surgical manipulation in any of the cerebral hemispheres is able to significantly block spontaneous ovulation by inhibiting the normal pattern of $\mathrm{GnRH}$ secretion and consequently that of gonadotropins (Morán \& Domínguez, 1995 and 1997).

Our results confirm that the dorsal pathways to the anterior hypothalamus carry information that participates in the neuroendocrine and endocrine mechanisms that lead to ovulation after an estrous cycle and allow us to suggest that the section of these pathways is capable of modifying the normal pattern of the GnRH secretion and thus the secretion of gonadotropins, necessary for the estrous cycle to develop properly.

The results in the experimental groups with false unilateral microinjection referring to ovulation lead us to affirm that the inhibition of the ovulatory capacity of the left ovary is necessarily the result of the alteration of nerve signals coming from one of the sides of the brain and that hypothetically they participate critically in the mechanisms that regulate the recruitment and follicular development of the left ovary without affecting the right ovary. There is very consistent evidence that proposes the existence of a direct nervous connection between the ovary and the CNS, particularly the hypothalamus (Advis et al, 1989; Domínguez et al, 1971; Domínguez et al, 1989; Fukuda et al, 1984; Mizunuma et al, 1983).

Recently, we have used intrahypothalamic microinjection techniques through a stainless steel cannula that remains embedded in one of the cerebral hemispheres for at least four complete estrous cycles. The results in the control groups with microinjection or false implant are opposite to our observations, since it is the right ovary that reduces its ovulatory capacity and the left one apparently compensates for it (Méndez \& Morán, 2001b; Morán, 2003; Morán et al, 2004).

MORÁN-PERALES, José Luis, SÁNCHEZ-GARCÍA, Octavio, GARCÍASUÁSTEGUI, Wendy Argelia and HANDAL-SILVA, Anabella. Effects of stereotactic surgery on the anterior hypothalamus (HA) on the estrous cycle: role stereotactic surgery on the anterior hypothalamus (HA) on the estrous cycle: role
of the dopaminergic system in spontaneous ovulation in the rat. ECORFAN of the dopaminergic system in spo 
These observations allowed us to suggest that the chronic effect caused by the presence of the permanent cannula induces a reorganization in the mechanisms that regulate ovarian function, that is, the system tends to readjust the nervous nature signals that reach the ovaries. This CNS plasticity phenomenon is evident in our group with false bilateral microinjection, since the ovulatory quota decreased significantly and it was because the left ovary also reduced its ovulant capacity.

The insertion of an empty cannula or the manipulation produced by the implantation of crystals of pure cholesterol on one side of the anterior hypothalamus is able to decrease the ovulatory rate (Morán \& Domínguez, 1995 and 1997). In these experiments, the administration of GnRH or estrogen restored ovulation in $100 \%$ of the cases, which suggested that the section of the thalamus pathways would lengthen the duration of the estrous cycle by affecting gonadotropin secretion by delaying the discharge GVR preoccupation. In our animals, the section of these thalamic pathways reproduces the observations of Morán and Domínguez (1995 and 1997), which seems to confirm that the thalamic structures dorsal to the anterior hypothalamus play a significant role in the integration of neuroendocrine signals that lead to proper discharge of GnRH.

The blockade of the dopamine receptors induced by microinjection of $15 \mu \mathrm{g}$ haloperidol on the right or left side of the anterior hypothalamus affected the development of the estrous cycle and the ovulatory response in the animals, regardless of the side on which the microinjection was performed, which suggests that dopaminergic information regarding either side of the anterior hypothalamus is important for endocrine and neuroendocrine mechanisms that culminate in rat ovulation to develop properly.

The microinjection of haloperidol on one side of the anterior hypothalamus is capable of affecting gonadotropin secretion and thereby ovarian function (Morán \& Domínguez, 1995 and 1997). It is known that dopamine antagonists decisively inhibit the adenohypophyseal discharge of prolactin (Neill, 1988). Our experimental model seeks to be adequate to study the influence of the dopaminergic system on the secretion of FSH and LH without directly involving the tuberoinfundibular system that controls the provulatory discharge of prolactin.
The predominance of a typical righthanded vaginal smear in animals with microinjection of the dopamine antagonist suggests the prolongation of the life of the corpus luteum, most likely maintained by the uncontrolled discharge of prolactin (Smith et al, 1975 and 1976). Thus, the high plasma concentrations of progesterone combined with low estrogen production, conditioned by low gonadotropin profiles, would prolong the negative feedback effect of sex steroids at the level of the hypothalamus, suppressing the pre-discharge of GnRH and therefore of gonadotropins (Keyes \& Wiltbank, 1988; McNelly, 1980).

In a previous study, Morán and Domínguez (1995) showed that when a unilateral implant with $10.0 \pm 0.3 \mu \mathrm{g}$ of haloperidol crystals is placed on the right or left side of the anterior hypothalamus in four-day regular estrous cycle rats, a Effective ovulation block, which can be partially reversed at $80 \%$ efficiency when GnRH is administered in animals. The results of this study allowed us to suggest that apparently the absence of ovulation is caused by the interruption of the mechanisms that control the tonic and phasic discharge of GnRH, in which estrogens play a crucial role. Consequently, blocking the dopaminergic receptors of the anterior hypothalamus affects the discharge of gonadotropins and therefore not enough estrogen would be produced.

This added to the lack of control of the prolactin discharge would cause the follicular development to stop, in a similar way to what happens during pregnancy, fall in the production of ovarian estrogens and therefore, absence of the signs of ovulation in the morning. of the expected estrus.

In another study, Morán and Domínguez (1997) showed that particularly on the day of estrus, the dopaminergic system of the anterior hypothalamus presents laterality in the control of spontaneous ovulation, as is the case with the cholinergic system (Cruz et al, 1989). The 10.0 $\pm 0.4 \mu \mathrm{g}$ implant of a $1: 1$ mixture of haloperidol and cholesterol crystals on the right side of the anterior hypothalamus effectively blocked ovulation in the morning of the expected estrus but the implant placed on the left side did not. 
This functional laterality could possibly be related to the positive feedback effect of estrogen that requires that the right side of the anterior hypothalamus remain intact (Morán \& Domínguez, 1995 and 1997) or with the asymmetric distribution of GnRH in the basal medial hypothalamus (Bakalkin et al, 1984; Gerendai et al, 1979).

In the present work, it was not considered to sacrifice the animals on the day of the expected estrus but to sacrifice them until the sign of the evident vaginal estrus (that is, the first estrus observed after the surgical interventions). In $98.6 \%(137 / 139)$ of the cases oocytes were found in the tubes (only two animals had to be counted the number of fresh luteal bodies). However, our observations also report changes that depend on the side of the hypothalamus in which the dopamine receptor blockade was performed. Apparently, in the animals they presented a Short Estral Cycle, a greater sensitivity to the pharmacological blockade of the right side of the anterior hypothalamus was observed that negatively affects the ovulant capacity of the left ovary accompanied by an increase in that of the right, but if the blockade of the receptors Dopamine was performed on the left side of the anterior hypothalamus, the result is the other way around. In animals with Long Estral Cycle, this cross laterality does not occur, however, the decrease in the ovulant capacity of the left ovary and increase in the right one occurs independently of the side of the hypothalamus on which the microinjection of haloperidol was performed.

Different studies have reported that for our animal strain the left ovary releases more oocytes than the right one (Domínguez et al, 1989) and that this difference is modified when the innervation of the ovaries is pharmacologically or surgically interrupted (Chávez et al, 1987; Cruz et al, 1986; Domínguez et al, 1989).

These results have postulated that the nervous information related to the ovaries participates in the modulation of the response to gonadotropins and in the control of follicular recruitment that leads to ovulation of each ovary. Our results support this hypothesis, since if changes in the ovulatory capacity of each ovary were observed as a result of anti-dopaminergic manipulations on one side of the anterior hypothalamus.
There are other studies that support our observations regarding the prolongation of the estrous cycle that follows intracerebral microinjection. In an experimental model similar to that used in the present work, we show that the first estrous cycle that follows brain surgery was significantly prolonged, but was particularly long in a group with bilateral microinjection of the EEDQ (selective antagonist of DA-1 receptors), although subsequent estrous cycles tended to normalize with respect to the group of adult rats with four-day cycles (Meléndez and Morán, 2002). Our results agree with this background and allow us to suggest that dopamine is a necessary signal for normal estrous cycles to develop.

The results of this work support the idea that the dopaminergic system of the anterior hypothalamus participates significantly in the integration of the neural and neuroendocrine signals that regulate the estrous cycle. Clemens et al. (1976) described the effects of electrolytic destruction of the rat's anterior hypothalamus. Bilateral lesion of the medial preoptic nucleus induced the prolongation of the estrous cycle, which showed prolonged periods of vaginal right-handedness in the animals. In this same study, the dicidoma test in the uterus of other animals, proved that this lesion induces the spontaneous appearance of pseudopregnancy stages.

The ovaries of the animals showed the presence of fresh luteal bodies at the end of each period of pseudopregnancy, which covered a period of 12 to 14 days. Daily administration of the dopamine agonist lergotril mesylate in animals with bilateral lesion of the preoptic area causes periods of pseudopregnancy to be reduced to four or five days, similar to a normal estrous cycle and presence of fresh luteal bodies in the ovaries of the animals.

Kalra (1974) showed that the disconnection of the pathways that separate the anterior hypothalamus from the middle eminence also induces the appearance of long estrous cycles in the rat, without affecting ovulation in the morning of the vaginal estrus. In these animals, the loss of the estrous cycle correlates with the decrease of the GnRH content in the middle eminence, which suggested that the control of the phasic discharge of the decapeptide comes from the rostral structures of the diencephalon. 
These results as a whole allowed us to suggest that the structures that control the tonic and phasic discharge of gonadotropins are located in the preoptic area and that dopamine is apparently the necessary signal for the synchronization of the estrous cycle with ovarian function.

Other results of our laboratory have shown that the systemic administration of haloperidol ( $2.5 \mathrm{mg} / \mathrm{kg}$ body weight) during the first half of the estrous cycle in four-day regular cycle rats induces changes in the secretion of gonadotropins that cause ovulation delay., that is, the estrous cycle extends significantly to 16.8 \pm 0.6 days (Morán et al, 2001; Ramírez-Ávila, 2001; Vargas-Torres, 2002).

\section{Conclusions}

The results of this study allow us to conclude that:

Stereotactic surgery performed in rats with regular four-day estrous cycles is capable of inducing the loss of the normal pattern of vaginal cytology expression.

In a short estrous cycle, the mechanical section of the neural connections that occurs when the needle of the microinjector is introduced into only one of the cerebral hemispheres of rats with regular four-day estrous cycles induces alteration of the nerve signals that reach the ovaries. inhibit ovulation of the left ovary.

In a long estrous cycle, the mechanical section of the neural connections of both cerebral hemispheres of rats with regular fourday estrous cycles induces alteration of nerve signals that reach the ovaries and result in decreased ovulatory capacity.

In a short estrous cycle, the effect of unilateral blockade of dopamine receptors in the anterior hypothalamus inhibits ovulation of the contralateral ovary, which is reflected in the fall in the total ovulatory quota in these animals.

In a long estrous cycle, the effect of unilateral blockade of dopamine receptors in the anterior hypothalamus results in the inhibition of ovulation of the left ovary, but stimulates that of the right, which compensates for the total ovulatory quota.

\section{References}

Adshi, E. Y., Jones, P. B. C. \& Shueh, A. J. W. (1981). Synergistic effects of glucocorticoids in the stimulation of progesterone production by follicle-stimulating hormone in cultured rat granulose cells. Endocrinology 109:1888-1894.

Advis, J.P., C.E. Ahmed \& S.R. Ojeda (1989). Direct hypothalamic control vasoactivo intestinal peptide (VIP) levels in the developing rat ovary. Brain Research Bulletin 22:605-610.

Arimura, A. (2000). Hypothalamic Hormones. En:" Neuroendocrinology in Physiology and Medicine". Capítulo 3. Eds. P.M. Conn \& M.E. Freeman. Humana Press. Pp.41-58.

Bakalkin, G.Y., V.V. Tsivezov, E.A. Sjutkin, S.P. Veselova, I.D. Novilov \& O.G. Krivosheev (1984). Laterization of LH-RH in the rat hypothalamus. Brain Res 296:361-364.

Baldessarini, R.J. (1989). Las drogas en el tratamiento de los transtornos psiquiátricos. En:" Bases Farmacológicas de la Terapéutica". 7a. edición. Capítulo 19. Eds. L.S, Goodman, T.W. Rall \& F. Murad. Editorial Médica Panamericana. pp 378-431.

Barraclough, C.A. (1983). The role of catecholamines in the regulation of gonadotropin secretion. Acta Morphol Hung 31:101-116.

Barraclough, C.A. \& P.M. Wise (1982). The role of catecholamines in the regulation of pituitary luteinizing hormone and follicle stimulating hormone secretion. Endocrine Rev 3:91-119.

Barry, J., G.E. Hoffman \& S. Wray (1985). LHRH-containing systems. En: "Handbook of Chemical Neuroanatomy: GABA and Neuropeptides in the CNS, Part I". Vol. 4. Capítulo IV. Eds. A. Björklund \& T. Hökfelt. Elsevier. Amsterdam. pp 166-215.

Björklund A. \& A. Nobin (1973). Fluorescence histochemical and microespectrofluorometric mapping of dopamine and noradrenaline cells groups in the rat diencephalon. Brain Res 51:193-205

Björklund A., O. Lundvall \& A. Nobin (1975). Evidence of an incertohypothalamic dopamine neuron system in the rat. Brain Res 89:2942. 
Carvey, M. P. (1998). Drug action in the central nervous system. Ed. M.P. Carvey. Oxford. New York. pp 214-225.

Chávez, R., M.E. Cruz \& R. Domínguez (1987). Differences in the ovulation rate of the right or left ovary in unilaterally ovariectomized rats: Effect of ipsi and contralateral vagus nerve on the remaining ovary. J Endocrinol 113:397-401.

Choudhury, S, R. Sharpe, P. Brown (1974). The effect of pimozide, a dopaminergic antagonist, on pituitary gonadotrophic function in the rat. $\mathrm{J}$ Reprod Fert 39:275-283.

Clemens, J.A., E.B. Smalsting \& B.D. Sawyer (1976). Studies on the role of the preoptic area in the control of reproductive function in the rat. Endocrinology 99:728-735.

Conn, M. (1994). The molecular mechanism of gonadotropin-releasing hormone action in the pituitary. En: "Physiology of Reproduction". 2th. Edition. Vol. I. Capítulo 32. Eds. E. Knobil \& J. Neill. Raven Press. New York, pp 18151832.

Cruz, M. E. R. Chávez \& R. Domínguez (1986). Ovulation, follicular growth and ovarian reactivity to exogenous gonadotrophins in adults' rats with unilateral or bilateral section of the vagi nerves. Revista de Investigación Clínica 38:167-171.

Cruz, M. E., L. P. Jaramillo \& R. Domínguez (1989). Asymmetric ovulatory response induced by a unilateral implant of atropine in the anterior hypothalamus of the cyclic rat. J Endocrinol 123:437-439.

D'angelo, S.A \& A.S. Kravats (1960). Gonadotropic hormone function in persistent estrous rats with hypothalamic lesions. Proc Soc Exp Biol Med 104:130-133.

Domínguez, R., M.E. Cruz \& R. Chávez (1989). Differences in the ovulatory ability between the right and left ovary are related to ovarian innervation. En: "Growth Factors and the Ovary". Eds. A.N. Hirshfield. Plenum Press. New York. pp. 321-325.
Domínguez, R., C.M. Gaitán, S.A. Méndez \& A. Ulloa- Aguírre (1987). Effects of catecholaminergic blockade by haloperidol or propranolol at different stages of the oestrous cycle on ovulation and gonadotrophin levels in the rat. J Endocrinol 113:37-44.

Domínguez, R. \& L. Riboni (1971). Failure of ovulation in autografted ovary of hemispayed rat. Neuroendocrinology 7: 164-170.

Domínguez, R., L. Riboni, D. Zipitria \& R. Revilla (1982). Is there a cholinergic circadian rhythm throughout the oestrous cycle related to ovulation in the rat? J Endocrinol 95: 175-180.

Domínguez, R., D. Zipitria, L. Riboni \& R. Revilla (1985). Differences in the ability of reserpine and chlorpromazine to block ovulation throughout the estrous cycle of the rat. J Interdisc Cycle Res 16:63-72.

Erickson, G.F. (1995). The ovary: Basic principles and concepts. En: "Endocrinology and Matabolism". Capítulo 17. Eds. P. Felling, J.D. Boxter \& L.A Frohman. 3th Edition. McGrawHill. New York. pp 973-1013.

Everett, J.W. \& H.M. Radford (1961). Irritative deposits from stainless steel electrodes in the preoptic rat brain causing release of pituitary gonadotropin. Proc Soc Exp Biol Med 108:604609

Everett, J.W. (1939). Spontaneous persistent estrous in a strain albino rats. Endocrinology 25:123-127.

Feder, H.H. (1981). Estrous ciclicity in mammals. En: "Neuroendocrinology of Reproduction: Physiology and Behavior". Sección III. Capítulo 10. Eds. N.T. Adler. Plenum Press. New York \& London. pp 279308.

Fink, G. (1979). Feedback actions of target hormones on hypothalamus and pituitary with special reference to gonadal steroids. Ann Rev Physiol 41:571-585.

Fink, G. (1988). Gonadotropic secretion and its control. En: "Physiology of Reproduction". 1th Edition. Vol. I. Capítulo 32. Eds. E. Knobil \& J. Neill. Raven Press, New York, pp 1349-1377. 
Fink, G., H.F. Stanley \& A. G. Watts (1983). Central nervous control of sex and gonadotropin release: Peptide and nonpeptide transmitter interactions. En: "Brain Peptides". Eds. D.T. Krieger, M.J. Brownstein \& J.B. Martin. John Wiley \& Sons. New York. pp. 413-435.

Freeman, M.E. (1988). The ovarian cycle of the rat. En: "Physiology of Reproduction". 1th Edition. Vol. II. Capítulo 45. Eds. E. Knobil \& J. Neill. Raven Press, New York, pp. 1893-1928.

Fukuda, M., K. Yamanouchi, Y. Nakano, H. Furuya \& Y. Arai (1984). Hypothalamic laterality in regulating gonadotropic function: Unilateral hypothalamic lesion and ovarian compensatory hypertrophy. Neurosci Letters 51:365-370.

Gerendai, I., W. Rotsytein, B. Marchetti \& V. Scapagnini (1979). LH-RH content changes in the mediobasal hypothalamus after unilateral ovariectomy. En: "Neuroendocrinology: Biological and Clinical Aspects". Proceedings of Serono Symposia. Vol. 19. Eds. A. Polleri \& R. McLeod. Academic Press. New York. pp. 97102.

González, K., Morán, J.L., Handal A. \& Reynoso A. (2016). El bloqueo farmacológico de los receptores ováricos a la dopamina altera el ciclo estral y la ovulación en la rata adulta. Revista de Sistemas Experimentales 3(7):27-45 (ISSN-2410-3950 ECORFAN) (2016).

Guzmán Herrera, N., Sánchez Gracía, O., Handal, A. \& y Morán, J.L. (2018). Dopaminergic receptor type 1 antagonism in rat ovarian tissue: effects on ovulation and ovarian compensatory hypertrophy. Journal Multidisciplinary Science UTSOE. V(X):12-27 (ISSN: 2395-860X LatinIndex).

Hàlasz, B. \& R.A. Gorski (1967). Gonadotrophic hormone secretion in female rats after partial or total interruption of neural afferents to the medial basal hypothalamus. Endocrinology 80:608-622.

Kalra, S.P. (1974). Role of estrogen in the restoration of $\mathrm{LH}$ release following stimulation of partially deafferentated hypothalamus in rat. Brain Res 68:297- 307.
Kamel, F. \& Kubajak, C. L. (1987). Modulation of gonadotropin secretion by corticosterone interaction with gonadal steroids and mechanism of action. Endocrinology 121:561-568.

Keyes, P.L. \& M.C. Wiltbank (1988). Endocrine regulation of the corpus luteum. Ann Rev Physiol 50: 465-482.

Kordon, C., S. V. Drouva, G. Martínez De La Escalera \& R. I. Weiner (1994). Role of classic and peptide neuromediators in the neuroendocrine regulation of luteinizing hormone and prolactin. En: The Physiology of Reproduction. 2th. Edición. Vol. I. Capítulo 27. Eds. E. Knobil \& J. Neill. Raven Press. New York, pp.1621-1681.

Kupfermann, I. (1985). Hypothalamus, limbic system and cerebral cortex: Homeostasis and arousal. En: "Principles of Neural Science". 2a. edición. Sección VIII. Capítulo 46. Eds. E.R. Kandel \& J.H. Schwartz. Elsevier. New York. pp 608-625.

Letras, D., Handal, A., Diaz, A. y Morán, J. (2016). La Sulpirida reduce la ovulación compensadora, pero incrementa la hipertrofia compensadora del ovario derecho en la rata hemi-ovariectomizada. ECORFAN Sistemas Experimentales 3 (7): 46-59.

Litter, M. (1988). Farmacología del Sistema Nervioso. En:"Farmacología Experimental y Clínica". 7ª Edición. 2a . Parte: Farmacología Especial. Sección 1. El ateneo, Buenos Aires. pp 179-429.

Luna, L.G. (1975). Manual of histology staining methods of the Armed Forces Institute of Pathology. McGraw-Hill Book Company. New York. pp 21 y 52.

MacKenzie, F.J., M.D. James \& C.A Wilson (1988). Changes in dopamine activity in the zone incerta (ZI) over the rat estrous cycle and the effect of lesions of the ZI on cyclicity: Further evidence that the incertohypothalamic tract has a stimulatory role in the control of LH release. Brain Res 444:75-83.

MacKenzie, F.J., A.J. Junter, C. Daly \& C.A. Wilson (1989). Evidence that the dopaminergic incertohypothalamic tract has a stimulatory effect on ovulation and gonadotrophin release. Neuroendocrinology 39:289-295. 
McCann, S.M., H. Mizunuma \& W.K. Samson (1983). Differential hypothalamic control of FSH secretion: a review. Psychoneuroendocrinology 8:299-303.

McCann, S.M., S.M. Ojeda, E. Vijayan \& R.L. Moss (1978). LH-releasing hormone (LHRH), its localization, mechanism of release and action in the anterior pituitary and CNS. En: "Clinical Psychoneuroendocrinolgy in Reproduction". Eds. L. Carenza, P. Pancheri \& L. Zichella. Academic Press. New York. pp 57-69.

McNelly, A.S. (1980). Prolactin and the control of gonadotrophin secretion in the female. J Reprod Fert 58:537-549.

Meléndez, E., Morán, C. \& Morán, J.L. (2002). Efectos de la microinyección de EEDQ en el hipotálamo anterior sobre el ciclo estral de la rata. Memorias del XLV Congreso Nacional de Ciencias Fisiológicas. Colima, Col. C-236.

Méndez Bermúdez A. \& Morán Perales J.L (2001a). Efectos de la microinyección del implante unilateral del antagonista dopaminérgico en el hipotálamo anterior en diferentes etapas del ciclo estral sobre la ovulación espontánea de la rata adulta.

Memorias en Extenso del XI Encuentro Regional De Investigadores En Flora Y Fauna De La Región Centro-Sur De La República Mexicana. Puebla, Pue. FA-20, pp 226-230.

Méndez A. \& Moran J.L (2001b). La sección de vías talámicas dorsales al hipotálamo anterior inhibe la ovulación de la rata adulta. Memorias del XLIV Congreso Nacional de Ciencias Fisiológicas, Monterrey, NL. C-7.

Mizunuma, H., L.R. De Palatis \& M. McCann (1983). Effect of unilateral orchidectomy on plasma FSH concentration: Evidence for direct neural connection between testes and CNS. Neuroendocrinology.37:291-296.

Miyake, A. (1988). Control of LHRH secretion in women and female rats. En: "Neuroendocrine Control of the Hypothalamo-Pituitary System". Ed. Hiroo Imura. Karger, pp 65-76.
Moran J.L. (2003). La microinyección de Haloperidol en el lado derecho del hipotálamo anterior inhibe la ovulación del ovario ipsilateral. Memorias del XLVI Congreso Nacional de Ciencias Fisiológicas. Aguascalientes, Ags. C-19.

Moran Perales J.L, Castillo Pérez A., Rodríguez Martínez C. \& Handal Silva, A. (2004). Cambios en la ovulación inducidos por la microinyección unilateral (MIU) del Haloperidol (HLP) en el Hipotálamo Anterior (HA) de la rata adulta. Memorias del XLVII Congreso Nacional de Ciencias Fisiológicas. Boca del Río, Ver. C-247. Morán, J.L. \& R. Domínguez (1995). Effects of the unilateral implant of haloperidol at the preoptic-anterior hypothalamic area, ovulation. Endocrine 3:399-401.

Morán, J.L. \& R. Domínguez (1997). Differences in the sensitivity of the right and left side of the preoptic anterior hypothalamic area to the effect of a unilateral implantation of haloperidol, performed on the day of oestrous, on spontaneous ovulation. Med Sci Res 25: 465466.

Morán, J.L., Ramírez, B., Meléndez, E. \& Handal, A. (2001) Efectos de la administración sistémica de haloperidol sobre la ovulación y la atresia folicular en el ovario de la rata adulta. Memorias del XLIV Congreso Nacional de Ciencias Fisiológicas. Monterrey, N.L. O-73.

Neill, J.D. (1988). Prolactin secretion and its control. En: "Physiology of Reproduction". Vol. I. Capítulo 33. Eds. E. Knobil \& J. Neill. Raven Press, New York, pp. 1379-1390.

NORMA OFICIAL MEXICANA NOM-062ZOO-1999 (1999). Especificaciones técnicas para la producción, cuidado y uso de los animales de laboratorio.

Palkovits, M. (1980). Functional anatomy of the 'endocrine' brain. En: "The Endocrine Functions of the Brain". Capítulo 1. Eds. M. Motta. Raven Press. New York. pp 1-16.

Paxinos, G. \& Watson, Ch. (1998). The Rat Brain: In stereotaxic coordinates. $4^{\text {th }}$. Edition, Academic Press.

Peppler, R. D. \& Jacobs, J. J. (1976). The effect of adrenal lectomy on ovulation and follicular development in the rat. Biol Reprod. 15:173178.

MORÁN-PERALES, José Luis, SÁNCHEZ-GARCÍA, Octavio, GARCÍASUÁSTEGUI, Wendy Argelia and HANDAL-SILVA, Anabella. Effects of stereotic surgery on the anterior hypothalamus (HA) on the estrous cycle: stereotactic surgery on the anterior hypothalamus (HA) on the estrous cycle: role of the dopaminergic system in spontaneous ovulation in the rat. ECORFAN Journal-Republic of Guatemala. 2019 
Pierce, J.G. (1988). Gonadotropins: chemistry and biosynthesis. En: "Physiology of Reproduction". 1th Edition. Vol. 1. Capítulo 31. Eds. E. Knobil \& J. Neill. Raven Press, New York, pp 1335-1348.

Ramírez, V.D., H.M. Feder \& C.H. Sawyer (1984). The role of brain catecholamines in the regulation of LH secretion: A critical inquiry. En: "Frontiers in Neuroendocrinology". Volumen III. Capítulo 2. Eds. L. Martini \& W.F. Ganong. Raven Press. New York. pp 27-71.

Ramírez-Ávila, B. (2001). Efectos de la administración secuencial de GnRH sobre la ovulación en ratas adultas con bloqueo farmacológico del sistema dopaminérgico. Tesis Profesional. Escuela de Biología de la BUAP.

Sánchez, M.A. \& R. Domínguez (1995). Differential effects of unilateral lesions in the medial amygdala on spontaneous and induced ovulation. Brain Res Bull 38:313-317.

Sanhera, M.K, S. Grady, W. Smith, D.J. Woodward \& J.C. Porter (1991a). Incertohypothalamic A13 dopamine neurons: Effect of gonadal steroids on tyrosine hydroxylase. Neuroendocrinology 53:268-275.

Sanhera, M.K., J. Anselmo-Franci \& S.M. Mccann (1991b). Effect on medial zona incerta lesions on ovulatory surge of gonadotrophins and prolactin in the rat. Neuroendocrinology 53: 433-438.

Sawyer, C.H. \& D.K. Clifton (1980). Aminergic innervation of the hypothalamus. Fed Proc 39:2889-2895.

Silverman, A.J. (1988). The gonadotropinreleasing hormone $(\mathrm{GnRH})$ Neuronal Systems: Immunocytochemistry. En: "Physiology of Reproduction". Vol. 1. Capítulo 29. Eds. E. Knobil \& J. Neill. Raven Press, New York, pp 1282-1304.

Simerly, R.B. (1995). Anatomical substrates of hypothalamic integration. En:" The Rat Nervous System". 2th. Edition. Eds. G. Paxinos. Academic Press. New York. pp 353-376.
Smith, M.S., M.F. Freeman \& J. D. Neill (1975). The control of progesterone secretion during the estrous cycle and early pseudopregnancy in the rat: prolactin, gonadotropin and steroid levels associated with rescuer of the corpus luteum of pseudopregnancy. Endocrinology 96:219-226.

Smith, M.S., McLean, B., and Neill, J.D. (1976) Prolactin: the initial luteotropic stimulus of pseudopregnancy in the rat. Endocrinology, 98: pp 1370-1377.

Tajasen, T. \& J.W. Everett (1967). Surgical analysis of the preoptico-tuberal pathway controlling ovulatory release of gonadotrophins in the rat. Endocrinology 81:1387-1396.

Tasaka, K., A. Miyake, T. Sakumoto \& T. Aono (1985). Dopamine decreases release of luteinizing hormone releasing hormone from superfused rat mediobasal hypothalamus. J Endocrinol Invest 8:373-376.

Tohyama, M. \& K. Takatsuji (1998). The catecholaminergic system. En: "Atlas of Neuroactive Substances and their Receptors in the Rat". Ed. M. Tohyama \& K. Takatsuji. Oxford University Press, pp 20-33.

Vargas-Torres, L.A. (2002). Efectos del bloqueo farmacológico de la información dopaminérgica sobre el ciclo estral de la rata: Análisis de los mecanismos que inhiben la función de los ovarios. Tesis Profesional. Escuela de Biología de la BUAP.

Venegas Meneses, B., Juárez Robelo, C.E., Handal Silva, A. \& Morán Perales, J.L. (2017). Efectos del bloqueo irreversible de los receptores dopaminérgicos del ovario sobre la ovulación espontánea de la rata adulta. Revista de Ciencias de la Salud 4(11): 11-23 (ISSN2410-3551 ECORFAN).

Venegas, B., Padilla, F., Juárez, C., Morán, J., Morán, C., Rosas, N., Handal, A \& Domínguez, R. (2015). Effects of ovarian dopaminergic receptors on ovulation. Endocrine, 50 (3):783796.

Welsh, T. H. \& Johnson, B. H. (1981). Stressinduced alterations in secretions of corticosteroids, progesterone, luteinizing hormone, and testosterone in bulls. Endocrinology. 109: 185-190. 
Wilson, C.A., M.D. James, J.P. Grierson \& D.R. Hole (1991). Involvement of catecholaminergic systems in the zona incerta in the steroidal control of gonadotrophin release and female sexual behavior. Neuroendocrinology 53:113123.

\section{Acknowledgments}

Our Academic Body (CA-090) thanks MVZ Francisco Ramos Collazo, director of the Claude Bernard Bioterio Autonomous University of Puebla, veterinarian assigned to the welfare of our experimental animals, all facilities and care for the development of draft. 